\title{
Triumph and tribulation for shallow water fauna during the Paleocene-Eocene transition; insights from the United Arab Emirates
}

\author{
Charlotte Beasley ${ }^{1 *}$, Laura Cotton ${ }^{2,3}$, Aisha Al-Suwaidi ${ }^{4}$, Leah LeVay ${ }^{5}$, \\ Appy Sluijs ${ }^{6}$, Clemens V. Ullmann ${ }^{1,7}$, Stephen P. Hesselbo ${ }^{1,7}$ and \\ Kate Littler ${ }^{1,7}$
}

With 9 figures and 1 table

\begin{abstract}
The Paleocene-Eocene transition was a time of short-term rapid climatic and biotic change, superimposed on a long-term warming trend. The response of shallow tropical carbonate systems to past rapid warming is important to understand in the context of ongoing and future anthropogenic global warming. Larger benthic foraminifera (LBF) were abundant and important components of shallow water ecosystems throughout the early Paleogene and are sensitive to environmental change, making them ideal organisms to track shallow marine biodiversity. Furthermore, through the use of integrated bio- and chemostratigraphy it is possible to correlate the shallow $(<100 \mathrm{~m})$ and deep water realms to create a regional stratigraphic framework for the time period. Here we present a new LBF biostratigraphic and high-resolution carbonate carbon isotopic record spanning the Paleocene-Eocene transition from the onshore sub-surface of the United Arab Emirates (UAE). Results show a turnover event in the LBF assemblage during the early Eocene, wherein there are a number of first and last occurrences of species. However, assemblages remain generally stable coincident with the large negative carbon isotope excursion interpreted to be the onset of the Paleocene-Eocene thermal maximum (PETM). Turnover in the LBF assemblage in the early Eocene likely occurred due to the crossing of a long-term climatic and oceanographic threshold. The impacts of this long-term climatic change on the overall biotic assemblage at this site are significant, with LBF outcompeting a previously diverse community of corals, gastropods, and bivalves to become the dominant carbonate producers through the Paleocene-Eocene transition. Despite this, modern studies suggest that LBF are not immune to impacts of anthropogenic climate change, perhaps due to the significantly higher rates of change in the modern compared to the Paleocene-Eocene transition.
\end{abstract}

Key words. Paleogene, larger benthic foraminifera, palaeoenvironment, biodiversity, PETM, shallow marine, carbonates

\footnotetext{
Authors' addresses:

${ }^{1}$ Camborne School of Mines, University of Exeter, Penryn Campus, Penryn, Cornwall, TR10 9FE, UK

${ }^{2}$ School of Earth Sciences, University of Bristol, Wills Memorial Building, Queens Road, Bristol, BS8 1RJ, UK

${ }^{3}$ Present address: School of Environment, Geography and Geosciences, Burnaby Building, Burnaby Road, Portsmouth, PO1 3QL, UK

${ }^{4}$ Earth Science Department, Khalifa University of Science and Technology, PO Box 127788, SAN Campus, Abu Dhabi, United Arab Emirates

${ }^{5}$ International Ocean Discovery Program, Texas A\&M University, 1000 Discovery Drive, College Station, TX 77845, USA

${ }^{6}$ Department of Earth Sciences, Faculty of Geosciences, Utrecht University, Marine Palynology and Paleoceanography, Laboratory of Palaeobotany and Palynology, Princetonlaan 8a, 3584CB, Utrecht, The Netherlands

7 Environment and Sustainability Institute, University of Exeter, Penryn Campus, Penryn, Cornwall, TR10 9FE, UK

*Corresponding author: c.beasley@exeter.ac.uk
} 


\section{Introduction}

The Paleocene and early Eocene ( $66-50 \mathrm{Ma})$ interval is characterised by long-term warming associated with changes in the carbon cycle (e. g., Eldholm and Thomas 1993, Zachos et al. 2008, Komar et al. 2013, Anagnostou et al. 2016). Shorter period Milankovitch cyclicity, changes in Earth's orbital configuration (i. e., eccentricity, obliquity and precession), also drove both variations in climate and perturbations to the carbon cycle during this period (Cramer et al. 2003, Lourens et al. 2005, Westerhold et al. 2011, Littler et al. 2014, Westerhold et al. 2017, Barnet et al. 2019). Against the background of warming during the late Paleocene to early Eocene, several transient global warming phases, so called 'hyperthermal' events of varying severity and duration, occurred that are likely to have been paced by Milankovitch cyclicity (e. g., Cramer et al. 2003, Lourens et al. 2005, Zeebe and Lourens 2019). These hyperthermals are associated with ocean acidification (Zachos et al. 2005, Stap et al. 2009), and negative carbon and oxygen isotope excursions as recorded in carbon bearing phases in both marine and terrestrial archives (Kennett and Stott 1991, Koch et al. 1992, Thomas and Shackleton 1996, Bolle et al. 2000, Lourens et al. 2005, Sluijs et al. 2009), providing strong evidence of rapid and massive injections of carbon into the ocean-atmosphere system (Dickens et al. 1995, 1997). During the largest of these hyperthermal events, the Paleocene Eocene Thermal Maximum (PETM; 56 $\mathrm{Ma}$ ), global climate rapidly warmed by $\sim 5^{\circ} \mathrm{C}$, with limited extratropical amplification (Dunkley Jones et al. 2013, Zeebe et al. 2014, Frieling et al. 2017). The PETM is recognised in geochemical records by a sudden negative carbon isotope excursion (CIE), followed by the 'body' of the CIE and relatively more gradual recovery to background levels, all of which is thought to have taken $\sim 170 \mathrm{kyr}$ (Röhl et al. 2007) but possibly more than $200 \mathrm{kyr}$ (Zeebe and Lourens 2019). In many deep sea sites the magnitude of this negative excursion, as recorded in marine carbonates by benthic foraminifera, is $\sim 2-3 \%$ (Kennett and Stott 1991, Bains et al. 1999, Zachos et al. 2003). However, some bulk marine organic matter records show a negative excursion of up to $\sim 8 \%$ in magnitude (Sluijs et al. 2006, Cohen et al. 2007, McInerney and Wing 2011). The differences in size and shape of the CIEs measured on specific substrates and regions are thought to relate to changes in the relative abundance of mixed components with different $\delta^{13} \mathrm{C}$ values within a measured substrate, changes in isotopic fractionation through physiological changes, changes in the isotope composition of the carbon source, and possibly effects of diagenetic alteration (Sluijs and Dickens 2012).

Following the PETM, the general warming of early Paleogene global climate continued, peaking at the early Eocene climatic optimum (EECO) between 25-50 Ma (Zachos et al. 2001, 2008, Bijl et al. 2009, Cramwinckel et al. 2018). High-resolution records of benthic foraminifera oxygen isotope values document a number of hyperthermal events within this early Eocene general warming trend (Galeotti et al. 2010, Littler et al. 2014, Lauretano et al. 2015, 2016, Westerhold et al. 2018, Barnet et al. 2019). These events include Eocene Thermal Maximum (ETM) -2 (also referred to as Elmo or H-1; Lourens et al. 2005, Sluijs et al. 2009, Stap et al. 2010) at $~ 53.7$ Ma and ETM-3 (or the "X" event; Agnini et al. 2009, Thomas et al. 2018) at $\sim 52.5$ Ma. Many of these early Eocene hyperthermals are thought to be orbitally paced by both the long ( $405 \mathrm{kyr})$ and short ( $\sim 100 \mathrm{kyr})$ eccentricity cycles, and the precession $(\sim 21 \mathrm{kyr})$ cycle (Cramer et al. 2003, Lourens et al. 2005, Galeotti et al. 2010, Zachos et al. 2010, Littler et al. 2014, Galeotti et al. 2019, Zeebe and Lourens 2019).

Throughout this early Paleogene interval larger benthic foraminifera (LBF) were abundant in tropical, shallow $(<100 \mathrm{~m})$ waters (Hottinger 1998, BouDagher-Fadel 2008). LBF are single-celled organisms which form more complex tests (shells) than smaller foraminifera (BouDagher-Fadel 2008). Many genera of LBF possess algal photosymbionts, similar to corals, restricting them to the marine photic zone (Haynes 1965). LBF are sensitive to environmental change, making them ideal organisms to study the effects of sudden global warming events, such as the PETM (Hallock and Glenn 1986). From the late Paleocene into the early Eocene LBF were increasingly important shallow water calcifiers, becoming the dominant carbonate producers in shallow oligotrophic environments as corals underwent decline (Scheibner and Speijer 2008a, Afzal et al. 2011, Zamagni et al. 2012). Coral reefs declined from the late Paleocene to early Eocene, possibly due to a number of stressors which include increased water temperatures and an increase in sediment load/nutrient supply (Zamagni et al. 2012). Over the Paleocene-Eocene transition, LBF underwent gradual turnover, as expressed in multiple low latitude sites including Spain, Egypt and Tibet (Scheibner et al. 2005, Pujalte et al. 2009, Zhang et al. 2018). LBF also experienced species diversification and increases in adult dimorphism and test size at this 
time (Hottinger 1998, Scheibner et al. 2005, Zhang et al. 2018); these changes are termed the larger foraminifera turnover (LFT). It remains uncertain whether this LFT event coincides with, and is therefore likely to be causally related to, the PETM (Pujalte et al. 2009, Scheibner and Speijer 2009), or if it predates this event and is therefore unrelated (Hottinger 1998, Zhang et al. 2013). The correlation of the LFT event to global biostratigraphy and chemostratigraphy would tie together shallow and deep water stratigraphies; however, most sites where the LFT is well expressed lack the additional stratigraphic control to definitively link to the global expression of the PETM (e.g., Pakistan; Afzal et al. 2010). Continued diversification of the LBF through the Paleogene created "hotspots" of high generic and species-level diversity which moved eastwards through this interval, from the Tethys to the current hotspot in the Indo-Pacific (Renema et al. 2008). Absolute timing and location for the beginning of this upturn in diversity is debated, with some suggesting that it started earlier in the late Paleocene to early Eocene in the eastern Tethys (Scheibner et al. 2005, Hottinger 2014), and others proposing a later start during the late middle Eocene in the western Tethys (Renema et al. 2008).

Contrary to this more gradual turnover and diversity increase of LBF in the shallow water domain, smaller benthic foraminifera in the deep water domain experienced a major extinction. Known as the benthic foraminifera extinction event (BEE; Thomas 1989, Thomas and Shackleton 1996, Thomas 1998, Alegret and Ortiz 2006), 30-50\% of known deep sea smaller benthic foraminifera species did not survive into the Eocene (Schmitz et al. 1996, Thomas 1998, 2007). It is suggested that the recorded $\sim 5^{\circ} \mathrm{C}$ of bottom water warming could have caused the BEE (Thomas et al. 2000, Winguth et al. 2012), either through warming of surface waters in regions of bottom water formation, or due to a switch of bottom water formation to lower latitudes (Thomas and Shackleton 1996). Additional factors affecting the smaller benthic community were marine waters that were increasingly corrosive to $\mathrm{CaCO}_{3}$, decreased oxygenation, and changes in productivity (Thomas 1998, 2007). It has also been suggested that the rapidity of the climate perturbations at the PETM, rather than the magnitude itself, caused the BEE (Thomas 2007). Across the gradual $(\sim 500$ kyr) global cooling at the Eocene-Oligocene transition, abyssal and bathyal benthic foraminifera show little change associated with the boundary itself, in contrast to the PETM (Coxall and Pearson 2007). This suggests an ability to adapt to such gradual changes and an inability to cope with the sudden change in palaeoenvironment at the onset of the PETM.

It is increasingly clear that hyperthermal events such as the PETM have a spatially heterogenous expression, where different regions experienced contrasting shifts in temperature (Sluijs et al. 2006, Aze et al. 2014, Sluijs et al. 2014, Frieling et al. 2017) and hydrology (Bolle and Adatte 2001, Bowen et al. 2004, Schmitz and Pujalte 2007, Bowen and Bowen 2008, Carmichael et al. 2017), as well as differing biological responses to these conditions (Speijer et al. 2012). For example, general circulation model (GCM) simulations for the PETM indicate that some regions, such as the eastern US coast and a number of localities around the Tethys, likely experienced increased precipitation, while the western US and the Angola Basin experienced aridification over the same interval (Carmichael et al. 2017). It is therefore important that the proxy record also has broad spatial coverage, both in terms of latitude/longitude and depth in the oceans.

Although there are excellent representative deep sea marine records of the late Paleocene to early Eocene from most of the major ocean basins, more multi-proxy records from the low latitudes and tropics are required in order to test these models. In particular, there is a dearth of data from shallow marine $(<100 \mathrm{~m})$, low latitude areas (Fig. 1). Although geochemical, sedimentological, palaeogeographical, and palaeobiological data spanning this interval are available from other east Tethyan sections (Nolan et al. 1990, Keen and Racey 1991, Alsharhan and Nairn 1995, Racey 1995, Schmitz et al. 1996, Charisi and Schmitz 1998, Speijer and Schmitz 2000, Speijer and Wagner 2002, Dupuis et al. 2003, Alegret and Ortiz 2006, Beavington-Penney et al. 2006, Dill et al. 2007, Khozyem et al. 2015, SerraKiel et al. 2016a, Giraldo-Gomez et al. 2018) comparable data from the United Arab Emirates (UAE) is of limited spatial and temporal resolution (Dill et al. 2007, Faris et al. 2014, Tomas et al. 2016). Importantly, the UAE is significantly further south (by $\sim 5^{\circ}$ ) and further east than most of these existing sites (Fig. 1). High-resolution, integrated geochemical and palaeoecological records from low latitude, shallow water sites of this age are important to constrain how these regions responded to both long-term changes in the climate and carbon cycle and geologically rapid events such as the PETM. A multi-proxy, integrated approach is key in order to be able to tie local stratigraphy to a global stratigraphic model, allowing for correlation from the shallow to the deep oceans. 

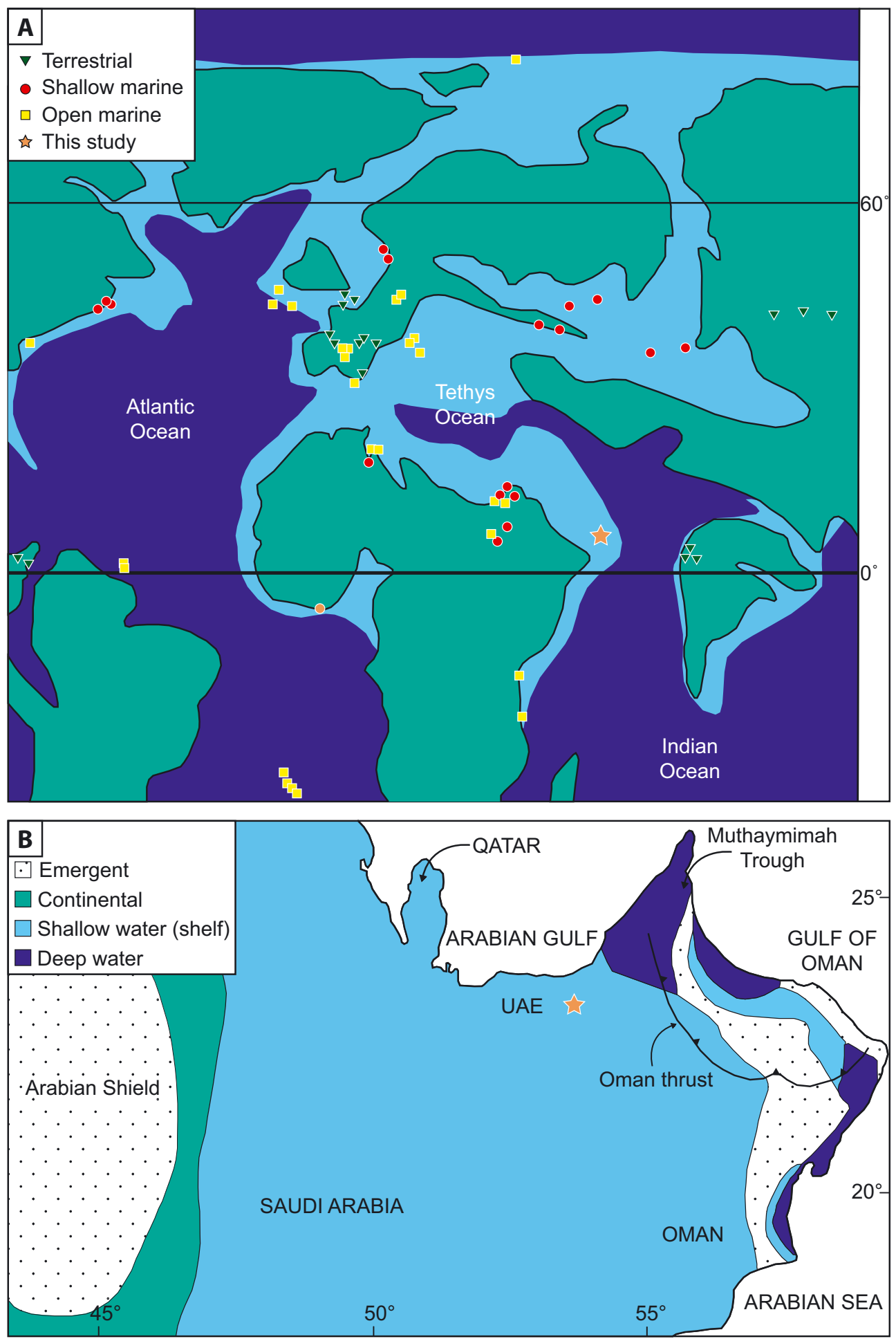

Fig. 1. A - Map of late Paleocene ( $\sim 56 \mathrm{Ma}$ ) palaeogeography (adapted from Dickson et al. 2015) displaying locations of PETM records (modified from McInerney and Wing 2011). Shallow marine defined as $<200 \mathrm{~m}$ water palaeodepth, open marine defined as $200 \mathrm{~m}$ to pelagic. Note the lack of sections from the southern and eastern Middle East, and the Arabian Sea. B - Palaeogeography of the Arabian Plate during the late Paleocene to early Eocene showing relationships between shallow and deeper water facies (modified from Ziegler 2001, Haq and Al-Qahtani 2005). Orange star indicates Core A location in both figures. 
Here we present an integrated, high-resolution LBF record with stable isotope and calcareous nannofossil stratigraphy from the subsurface of onshore United Arab Emirates (UAE) covering the late Paleocene into early Eocene interval. This area previously lacked integrated, high-resolution palaeoclimatic data from this globally important time interval (Fig. 1). The core investigated in this study provides an opportunity to examine a long-ranging interval in which the LBF response to global climate change can be tied to the global isotope and biostratigraphy. The response of the low latitude and shallow water domains to past climate perturbations provides important insight for the future response of these fragile ecosystems to anthropogenic climate change.

\section{Geological setting of study area}

In order to address the outstanding questions surrounding the response of the shallow marine realm to the climatic changes during the late Paleocene to early Eocene, we produced new geochemical and palaeontological records from "Core A", onshore UAE (Fig. 1). Core A was recovered by Abu Dhabi National Oil Company (ADNOC) and may have economic significance, and as such the specific core name and precise locality cannot be published. Located in the western UAE, Core A is from an area otherwise dominated by sandy desert with no available outcrop. Core A was logged at a high-resolution along the entirety of its length revealing the core consists of $\sim 383 \mathrm{~m}$ of dominantly shallow $(<100 \mathrm{~m})$ marine carbonate sediments, rich in bioclasts (Fig. 2). The examined core was previously split and slabbed, allowing for sedimentary structures and biota to be observed. The top of the core starts at approximately $985 \mathrm{~m}$ depth below surface (mbs), extending to $\sim 1350 \mathrm{mbs}$ at the base of the core. For the purpose of this study $985 \mathrm{mbs}$ was used as the zero level and will be referred to as such for the rest of the text.

\section{Methods}

\subsection{Microfossils}

\subsubsection{Larger benthic foraminifera}

A total of 48 samples were analysed for LBF biostratigraphy through the use of 56 petrological thin sections. Multiple thin sections were made for some samples in order to aid identification of LBF; identification to species level requires the specimen to be orientated with the section passing through the first chamber (proloculus), thus duplicate thin sections were made in key intervals at right angles to one another. Standard petrographic thin sections were used for identification of LBF taxa and ground to a thickness of $50 \mu \mathrm{m}$ in order to ensure skeletal grains were identifiable. Samples were taken approximately every $20 \mathrm{~m}$ for the lower part of the core, increasing to a $\sim 5 \mathrm{~m}$ resolution from $\sim 50 \mathrm{~m}$ depth to the top of the core (Fig. 2). Taxonomy follows that of Hottinger (2014).

\subsubsection{Calcareous nannofossils}

Sixteen samples from between $5.8-372.6 \mathrm{~m}$ were studied in order to provide a biostratigraphic framework. Samples that contained a higher percentage of marl were chosen for analysis on the basis that preservation was likely to be better in the finer grained sediment. Smear slides were prepared using standard techniques (Bown and Young 1998) and the slides used $24 \mathrm{~mm}$ x $40 \mathrm{~mm}$ cover slips. Transects across the cover slip were made at x630-1000 magnification using a Zeiss Axioscope A1. The transects were intended to capture the whole cover slip, but some fields of view may have been missed.

Total nannofossil abundance in the slide was visually assessed using the following criteria (Clemens et al. 2016): $\mathrm{D}=$ dominant ( $>90 \%$ of sediment particles in a field of view); $\mathrm{A}=$ abundant (50-90 \% of sediment particles); $\mathrm{C}=$ common $(10-50 \%$ of sediment particles); $\mathrm{F}=$ few $(1-10 \%$ of sediment particles $) ; \mathrm{R}=$ rare $(<1 \%$ of sediment particles); $\mathrm{B}=$ barren (no specimens present).

The relative abundance of nannofossil species was not collected due to the overall rarity of fossils. In Figure 5, the presence of a species is denoted with an ' $\mathrm{X}$ ', and questionable species occurrences due to poor preservation are marked with a '?'.

The preservation state of the nannofossils was qualitatively described using the categories (Clemens et al. 2016): $\mathrm{VG}=$ very good (no evidence of dissolution and/or recrystallisation, no alteration of primary morphological characteristics, and specimens identifiable to species level); $\mathrm{G}=$ good (little evidence of dissolution and/or recrystallisation, primary morphological characteristics only slightly altered, and specimens identifiable to species level); $\mathrm{M}=$ moderate (specimens exhibit some etching and/or recrystallisa- 
tion, primary morphological characteristics somewhat altered, and most specimens identifiable to species level); $\mathrm{P}=$ poor (specimens severely etched or overgrown, primary morphological characteristics largely destroyed, fragmentation has occurred, and specimens could not be identified to species and/or genus level).

The biostratigraphic classification of the study succession is based upon the Martini (1971) NP zonation (Agnini et al. 2007, 2014). Nannofossil taxonomy follows Perch-Nielsen (1985) and the Nannotax database (Young et al. 2019).

\subsubsection{Palynomorphs}

Three samples were processed for palynology. These samples bordered the Paleocene-Eocene boundary, with slides at $7.4 \mathrm{~m}, 8.2 \mathrm{~m}$, and $153.3 \mathrm{~m}$ from the top of the core. Palynological slides were prepared at the National Oceanography Centre, University of Southampton. Approximately $5 \mathrm{~g}$ of roughly crushed rock was treated with $30 \% \mathrm{HCl}$ to remove carbonates, followed by decant washing to a neutral $\mathrm{pH}$. Samples were further demineralised in $60 \% \mathrm{HF}$ followed by decant washing again to a neutral $\mathrm{pH}$ and sieved at $15 \mu \mathrm{m}$. Samples were then placed in glass beakers and briefly boiled in $30 \% \mathrm{HCl}$ to solubilise neoformed fluorides that were then removed by diluting into a large volume of water and re-sieving. Residues were then vialed, with strew slides made and mounted in Elvacite $2044^{\mathrm{TM}}$. Residues were analysed at Utrecht University, Laboratory of Palaeobotony and Palynology for general palynological content, with emphasis on dinoflagellate cysts (dinocysts) following the taxonomy of Williams et al. (2017).

\subsection{Carbon and oxygen isotope analysis}

The bulk carbonate fraction from a total of 710 samples was analysed for stable carbon and oxygen isotopes. This consisted of 379 samples from the top $79 \mathrm{~m}$ of Core A, at a resolution of $10 \mathrm{~cm}$, and 331 samples from the remaining $\sim 300 \mathrm{~m}$, at a resolution of approximately $1 \mathrm{~m}$. These samples were drilled using a micro-drill, choosing fresh surfaces and avoiding macrofossil material. The bulk rock powder was weighed at 500 $\pm 50 \mu \mathrm{g}$ for each sample and subsequently analysed for $\delta^{13} \mathrm{C}$ and $\delta^{18} \mathrm{O}$ values using a SerCon 20-22 Gas Source Isotope Ratio Mass Spectrometer (GS-IRMS) in the Environment and Sustainability Institute, University of Exeter. Samples were weighed using a MSE3.6P-000-DM Sartorius Cubis ${ }^{\circledR}$ Micro Balance.
Standards and samples are reported in $\delta$-notation relative to VPDB (Vienna Pee Dee Belemnite). Each complete run of analysed samples consisted of 80 samples plus 22 aliquots of the in-house standard CAR (Carrara Marble, $\delta^{13} \mathrm{C}=+2.10 \%$ VPDB; $\delta^{18} \mathrm{O}=$ $-2.03 \%$ VPDB) and 8 aliquots of the in-house standard NCA (Namibia Carbonatite, $\delta^{13} \mathrm{C}=-5.63 \%$ vPDB; $\delta^{18} \mathrm{O}=-21.90 \%$ VPDB). Standards were also weighed at $500 \pm 50 \mu \mathrm{g}$.

All samples were flushed with $\mathrm{He}$ for 80 seconds before manual injection of $\sim 100 \mu \mathrm{L}$ of nominally anhydrous phosphoric acid. Samples were measured alternating with a reference gas in continuous flow mode (Spötl and Vennemann 2003). For the results shown in this report the average 2 sd repeatability of CAR was found to be $0.06 \%$ for $\delta^{13} \mathrm{C}$ and $0.14 \%$ for $\delta^{18} \mathrm{O}$ and average $2 \mathrm{sd}$ repeatability of NCA was $0.09 \%$ for $\delta^{13} \mathrm{C}$ and $0.30 \%$ for $\delta^{18} \mathrm{O}$ (Table S1, Supplementary Information).

\subsection{Percentage calcium carbonate analysis}

Percentage calcium carbonate $\left(\% \mathrm{CaCO}_{3}\right)$ data were determined as a by-product of the carbonate carbon and oxygen isotope analysis detailed in Section 3.2. Bulk sediment samples were weighed before analysis (as above), and this known amount was dissolved using anhydrous phosphoric acid. Once dissolved the samples release $\mathrm{CO}_{2}$, and through calibration of the size of this $\mathrm{CO}_{2}$ peak relative to known standards, the \% $\mathrm{CaCO}_{3}$ could be determined for each sample, yielding a 2 sd reproducibility of $\pm 2.3 \%$ for the in-house standard NCA ( $\mathrm{n}=79)$ (e. g., Razmjooei et al. 2020).

\subsection{Inductively coupled plasma optical emission spectroscopy (ICP-OES)}

A total of 34 bulk carbonate samples were analysed using ICP-OES, at a resolution of approximately $10 \mathrm{~m}$, for their trace element signal. Bulk samples were micro-drilled, choosing fresh surfaces and avoiding macrofossil material. Bulk rock powder was weighed at $850 \pm 100 \mu \mathrm{g}$ using a MSE3.6P-000-DM Sartorius Cubis ${ }^{\circledR}$ Micro Balance. The samples were dissolved using $2 \%$ nitric acid and diluted to a nominal $\mathrm{Ca}$ concentration of $25 \mu \mathrm{g} / \mathrm{g}$. These solutions were run on an Agilent 5110 Series machine at the University of Exeter Penryn Campus with three multi-elemental standards consisting of $12 \mathrm{JLS}-1,8 \mathrm{AK}$ and 4 BCQC. Table S2 (Supplementary Information) shows 


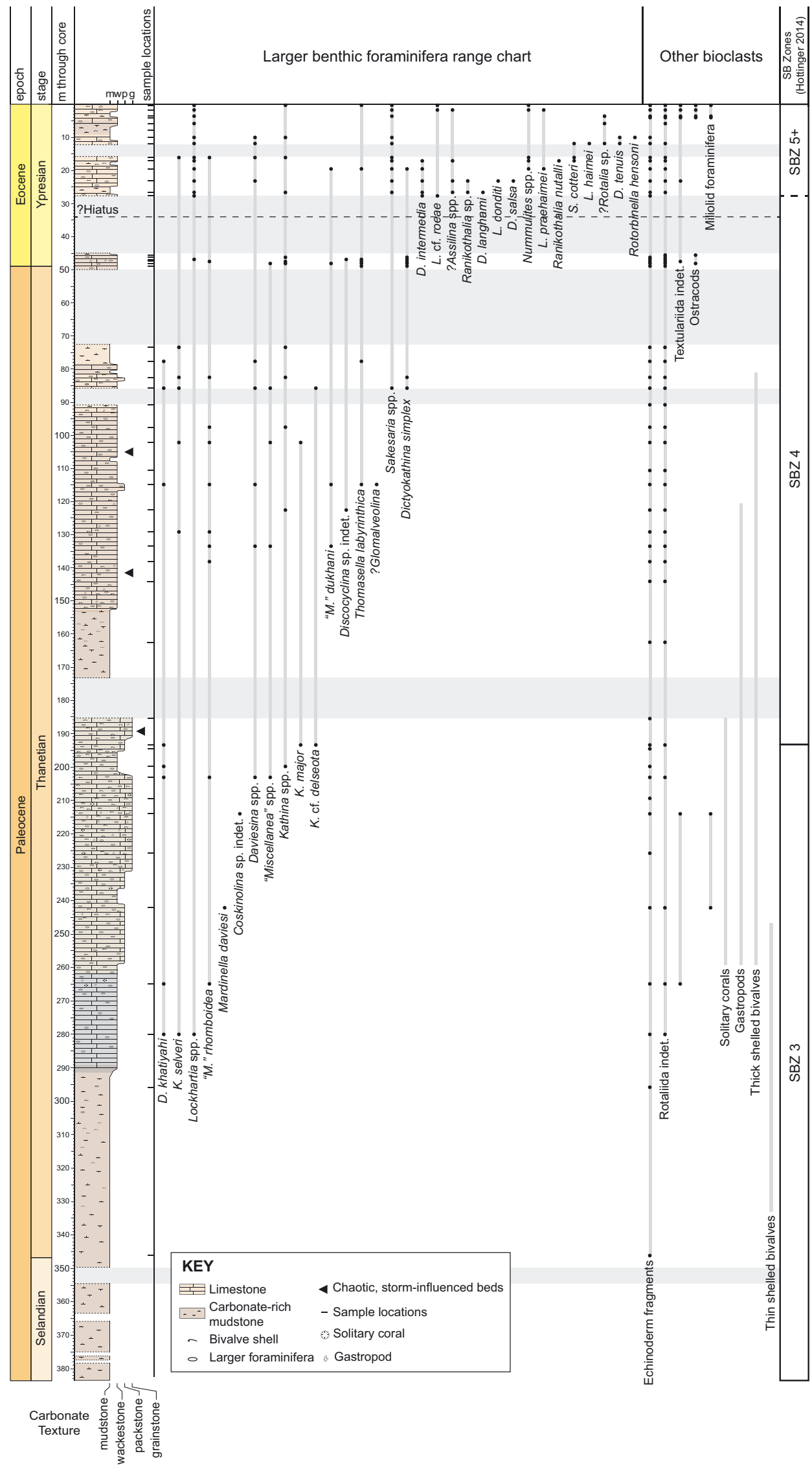

Fig. 2. $\log$ of Core A and range chart of LBF species and genera observed, arranged by first occurrence in the core. Also included are other bioclasts observed in the core. Shallow benthic (SB) zonation scheme from Hottinger (2014). Colours of $\log$ directly reflect changes in lithology colour of core. Horizontal grey boxes mark core gaps. 
the suite of analysed elements with their 6 sd quantification limits. Data repeatability (2 relative standard deviations) is generally better than the larger value of either the quantification limit (for low element/Ca ratios) or $1 \%$ of the measured element/Ca ratio (for high element/Ca ratios).

\subsection{Optical cathodoluminescence microscopy}

Three representative thin sections from Core A were observed using a Nikon Eclipse LV100ND with CITL Analytical Instruments MK 5-2 cold cathodoluminescence microscope in order to observe areas of possible diagenetic alteration. Investigated samples were from $\sim 0.2 \mathrm{~m}, \sim 16.1 \mathrm{~m}$, and $\sim 85.6 \mathrm{~m}$, within bioclastic facies dominated by LBF. Impurities within the carbonate rocks affect the luminescence of the material, with $\mathrm{Mn}^{2+}$ activating luminescence and $\mathrm{Fe}^{2+}$ quenching it. The ratio of these elements, therefore, control the intensity of luminescence in a material (Adams and MacKenzie 1998).

\subsection{Wireline logging}

Wireline logging data, collected during drilling operations, were obtained from ADNOC. The wireline undifferentiated gamma ray data has been used in this study; spectral gamma ray was not available. Measurements were taken approximately every $15 \mathrm{~cm}$ downcore.

\section{Results}

\subsection{Sedimentology}

Within the core there are three distinct lithofacies (Fig. S1): 1) Marl with few or no bioclasts; 2) LBFrich bioclastic wackestone/packstone and; 3) Bioclastic grainstone with LBF, gastropods, bivalves, and solitary corals. In the lower part of the core, from 383-285 m, facies type 1 dominates with occasional thin-shelled bivalves and rare or absent photosymbiont bearing organisms, such as corals or LBF. This lower interval transitions up into facies type 3 from $\sim 285-185 \mathrm{~m}$. From $\sim 173 \mathrm{~m}$ upwards in the core there are a series of shallowing-up parasequences on the order of 10's of metres (Fig. 2). Marls with thin-shelled bivalves and LBF, suggestive of a low energy environment, grade upwards into more bioclastic facies (facies type 2) with thicker shelled bivalves, occasional gastropods and abundant LBF. Within these parasequences there are intermittent grainstone beds composed of broken up, poorly sorted bioclasts (Fig. 2). The nature of these beds is suggestive of storminfluenced deposits.

Within the observed sedimentary sequence there is no evidence of sub-aerial emergence of the platform indicating that there is an absence of large regression episodes on the platform. However, there are large gaps in the record at the top of the core where no sediments were recovered during drilling.

\subsection{Micropalaeontological results}

\subsubsection{The larger benthic foraminiferal assemblages}

The LBF assemblages were examined throughout Core A (Figs. 2 and 3) in order to construct the basis of an age model and determine palaeoecological changes through the Paleocene-Eocene interval. Biostratigraphy of LBF uses regional schemes; within the Tethyan region this is the shallow benthic zonation (SB) scheme (Papazzoni and Pignatti 2019), which is the closest and most widely used in the Arabian Peninsula region. To create the biostratigraphic model, the SB Zonation scheme constructed in the Tethyan region, updated and modified in nearby areas of the Arabian Plate, was utilised (Serra-Kiel et al. 1998, Scheibner and Speijer 2009, Serra-Kiel et al. 2016a, Serra-Kiel et al. 2016b).

The LBF assemblage in Core A consists largely of the genera Daviesina, Kathina, Lockhartia, Miscellanea, Sakesaria, Ranikothalia, and Nummulites, all of which are typical for the region. From the bottom of Core A to $\sim 50 \mathrm{~m}$ the LBF assemblages are composed

Fig. 3. Selected late Paleocene to early Eocene LBF from Core A. 1) Miscellanea "rhomboidea" Kuss and Leppig 1989, range undefined, 133.5 m. 2) Daviesina khatiyahi Smout 1954, Zone SB 3-4, 194.6 m. 3) Kathina selveri Smout 1954, Zone SB 3-4, 280 m. 4) Lockhartia cf. conditi (Nuttall 1926), Zone SB 4-8, 23.1 m. 5) Nummulites sp., Zone SB 5+, 16.1 m. 6) Sakesaria cotteri Davies and Pinfold 1937, Zone SB 5-7, 17.1 m. 7) Dictyokathina simplex Smout 1954, Zone SB 3-4, 194.6 m. 8) Mardinella daviesi (Henson 1950), Zone SB (?-)4, $242.1 \mathrm{~m}$. 9) Thomasella labyrinthica Grimsdale 1952, Zone SB 4(-5?), $115 \mathrm{~m}$. 10) Miscellanea dukhani Smout 1954, Zone SB 4-5, 133.5 m. 11) Ranikothalia nuttalli (Davies 1927), Zone SB 4, $17.1 \mathrm{~m}$. 


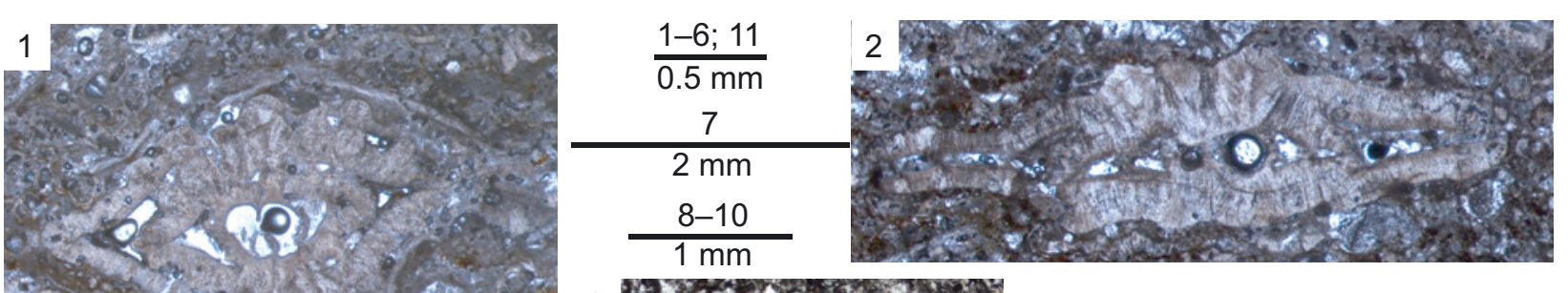

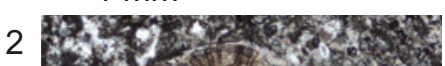
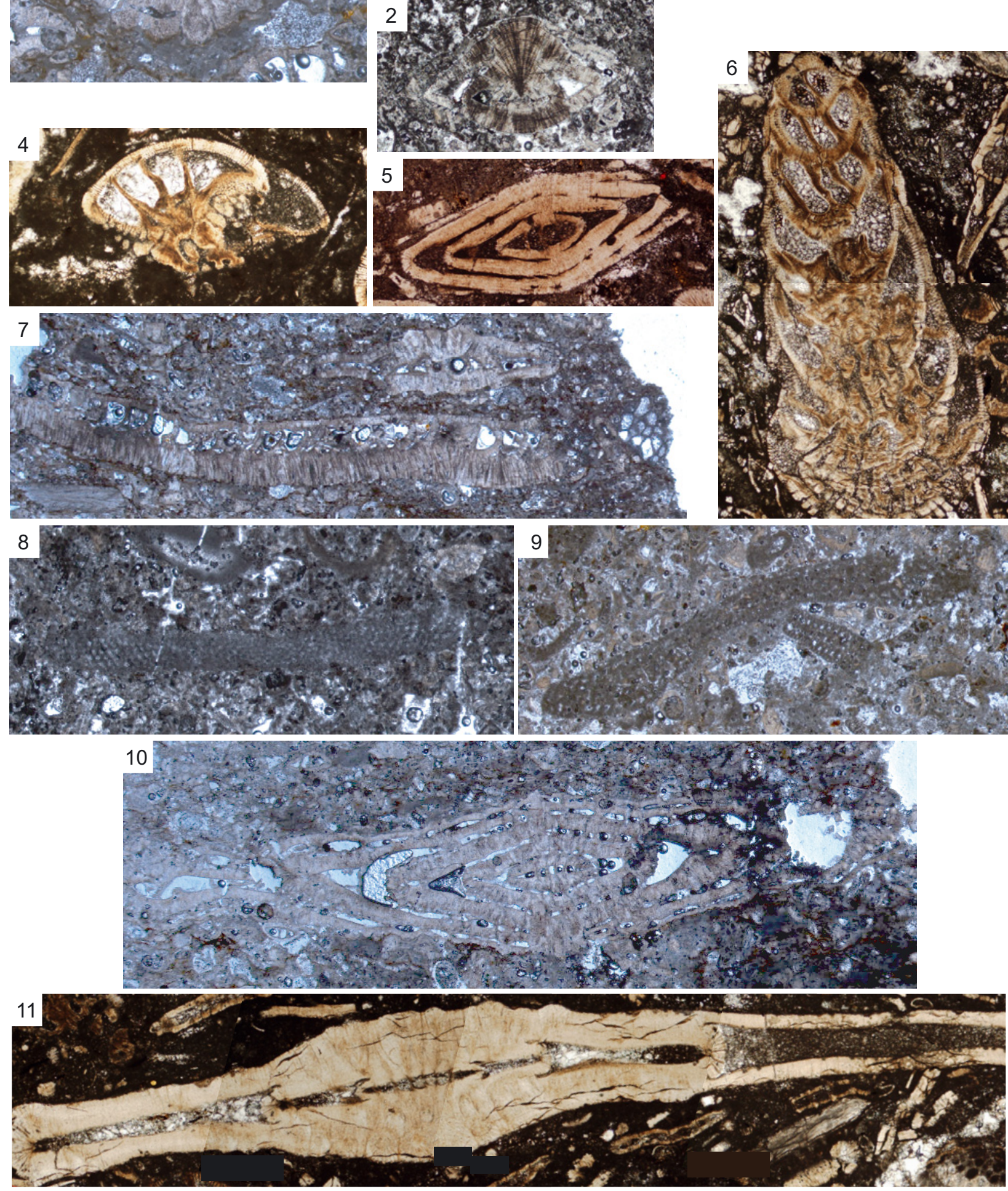


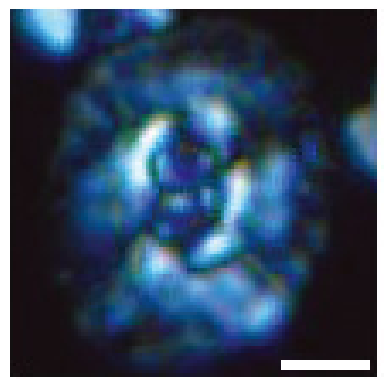

1
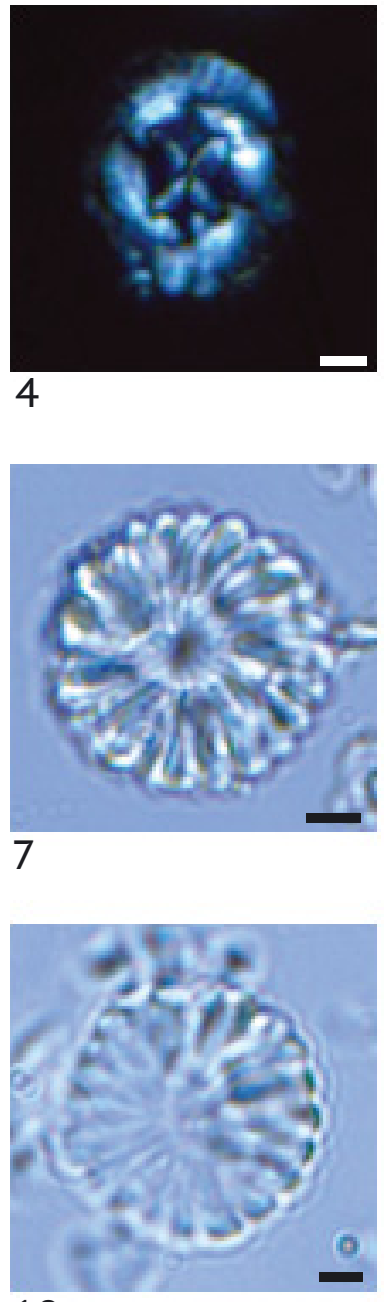

10

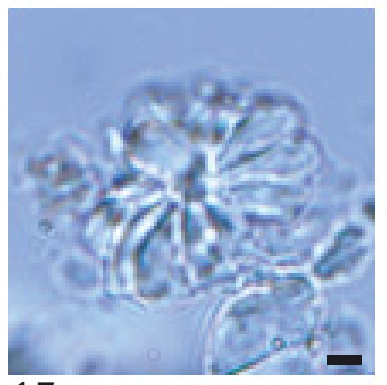

13
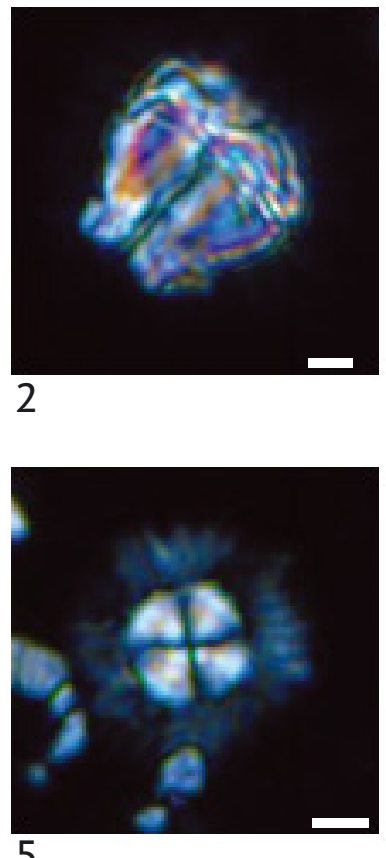

5

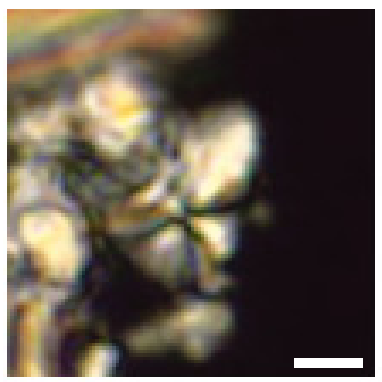

8

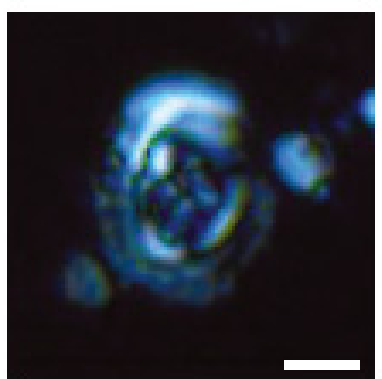

11

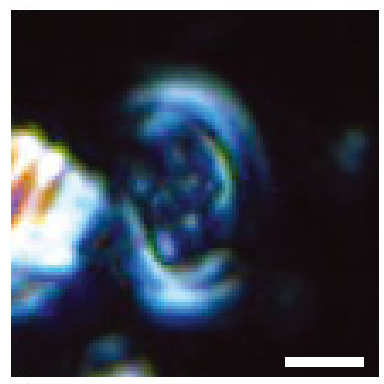

14
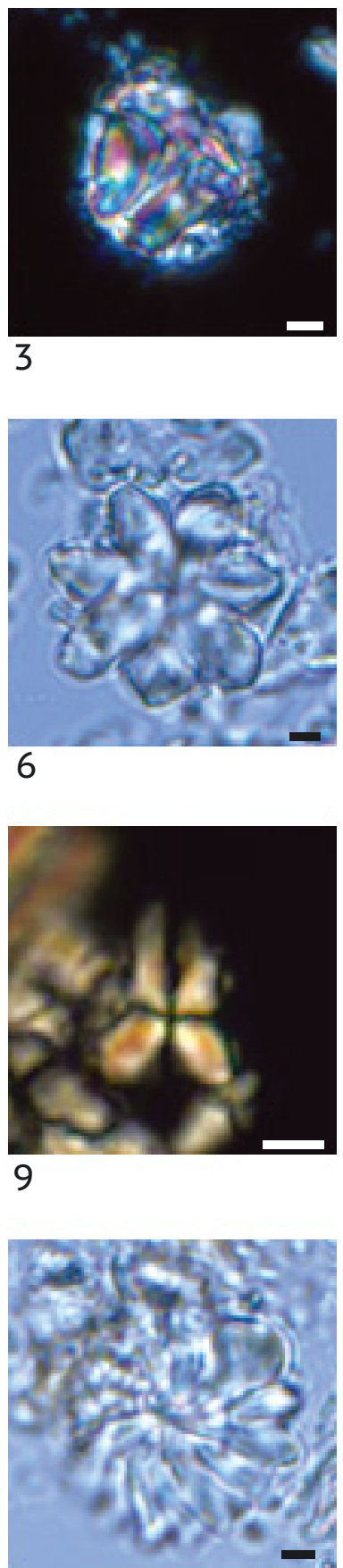

12

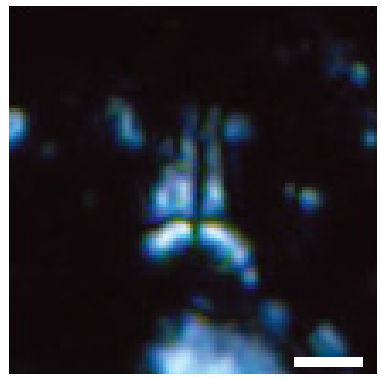

15 
Fig. 4. Select nannofossils from Core A. The horizontal scale bar is 2 microns. 1) Chiasmolithus nitidus ? PerchNielsen 1971, 372.6 m. 2, 3) Lithoptychius janii PerchNielsen 1971, 372.6 m. 4) Chiasmolithus consuetus (Bramlette \& Sullivan 1961), Hay \& Mohler 1967, 368.6 m. 5) Bomolithus megastypus (Bramlette \& Sullivan 1961), Bown 2010, 170.2 m. 6) Discoaster nobilis ? Martini 1961, 170.2 m. 7) Discoaster multiradiatus Bramlette \& Riedel 1954, 77.7 m. 8, 9) Sphenolithus apoxis ? Bergen \& de Kaenel 2017, 77.7 m. 10) Discoaster multiradiatus Bramlette \& Riedel 1954, 27.7 m. 11) Campylosphaera eodela Bukry \& Percival 1971, 27.7 m. 12, 13) Discoaster barbadiensis Tan 1927, $16.1 \mathrm{~m}$. 14) Campylosphaera eodela Bukry \& Percival 1971, 16.1 m. 15) Sphenolithus orphanknollensis Perch-Nielsen 1971, 11.9 m.

primarily of the genera Daviesina, Miscellanea, Kathi$n a$ and Dictyokathina, diagnostic of Zones SB 3 and SB 4, which broadly correlate to a mid to late Paleocene age (Serra-Kiel et al. 1998). The first occurrence (FO) of Kathina major and K. delseota and the FO of Miscellanea dukhani occur at $\sim 193$ and $\sim 134$ metres respectively (Hottinger 2009, 2014), placing the Zone SB 3-4 boundary at approximately $193 \mathrm{~m}$ (Fig. 2). Between 134 and $46 \mathrm{~m}$ the assemblages remain relatively consistent, with 5 first occurrences and 4 last occurrences recorded. There is then a core gap between $\sim 46-27 \mathrm{~m}$.

Above $\sim 27 \mathrm{~m}$ in the core the genera Sakesaria and Nummulites along with small rotaliids and miliolids dominate the assemblages, indicative of Zone SB 5 and higher, approximately correlating to the early Eocene (Serra-Kiel et al. 1998, Scheibner and Speijer 2009). A more precise SB Zone cannot be determined due to a lack of age diagnostic species in these samples. Following Serra-Kiel et al. (1998), Scheibner et al. (2005) and Scheibner and Speijer (2009) the Zone SB $4-5$ boundary is defined by the last occurrence (LO) of Dictyokathina simplex and all representatives of the genus Miscellanea, along with the FO of Sakesaria cotteri, Ranikothalia nuttalli, Rotalia spp. and Nummulites spp. This suggests the boundary between Zone SB 4 and 5 is between 27 and 16 metres, within which Ranikothalia nuttalli, Sakesaria spp. and Nummulites spp. all have first occurrences preceding the last occurrences of Dictyokathina simplex and the genus Miscellanea.

Within the defined Zone SB 4-5 interval (27-16 m; Fig. 2), LBF species richness increases over approximately $10 \mathrm{~m}$ of stratigraphy. The assemblages from the bottom of the core to $\sim 45 \mathrm{~m}$ is relatively uniform, with 6 genera and 7 species in Zone SB 3 and 9 genera and 9 species in Zone SB 4. From $\sim 45 \mathrm{~m}$, Zone SB 5 and higher, the number of genera increases to 11 and the number of species increases substantially to 16 .

\subsubsection{Calcareous nannofossil biostratigraphy}

In general, nannofossils are poorly preserved (Fig. 4) and have abundances ranging from rare to few when present (Fig. 5). A total of 29 species plus 7 undifferentiated genera are recognised (Fig. 5). The estimated age assignments are primarily based upon the assemblage and documented ranges of non-marker species, as few marker species are present in the samples. We caution that the presented zones are estimates that provide age constraints and, without the presence of marker taxa, cannot be regarded as precise. The samples range from middle Paleocene (Zone $\sim \mathrm{NP}$ $4-6)$ to the early Eocene ( NP 11). Of the 16 samples, approximated biozone ranges are assigned to 9 of them. Where approximate ages are stated, they are calibrated to GTS2012 (Gradstein et al. 2012).

The base of the core $(\sim 370 \mathrm{~m})$ contains Lithoptychius janii, which constrains the age of these sediments to likely be within the NP 4-6 biozones (Varol 1989, Young et al. 2019) and corresponds to the middle Paleocene. Below the large gaps in the core, at $\sim 78 \mathrm{~m}$, the first appearance of the robust marker species Discoaster multiradiatus is present indicating late Paleocene age (marker species for the base of Zone NP 9; Martini 1971). The top of the core ( $28 \mathrm{~m}$ and above) contains Campylosphaera eodela, D. multiradiatus, D. barbadiensis, Coccolithus latus and Sphenolithus orphanknollensis. This assemblage suggests this sample likely falls within or near Zone NP 11 (Agnini et al. 2007, Shamrock and Watkins 2012) correlating to the early Eocene. The primary marker for the base of NP 11, Tribrachiatus contortus, is absent, which may be due to poor preservation or ecological exclusion. The change in biozones from $\sim \mathrm{NP} 9$ to NP 11 that occurs between $\sim 78 \mathrm{~m}$ and $\sim 28 \mathrm{~m}$, suggests either a hiatus in sedimentary deposition or that stratigraphic condensation occurred. More detailed descriptions of the calcareous nannofossil assemblages are given in the Supplementary Information.

\subsubsection{Palynology}

In the three samples analysed for palynology the main component is amorphous organic matter (AOM), most likely of marine origin, with abundant organic linings of benthic foraminifera, sometimes abundant phyto- 


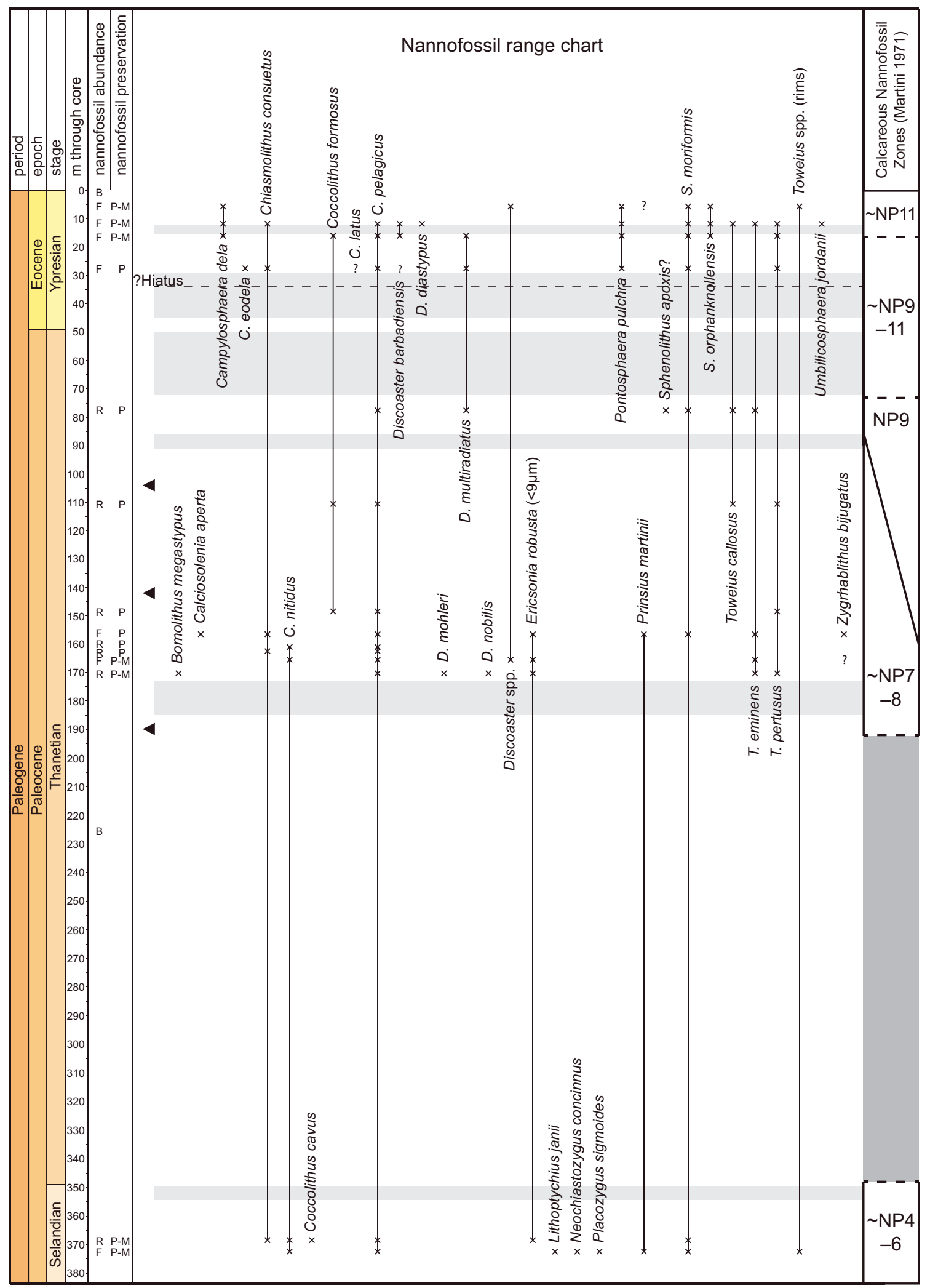

Fig. 5. Calcareous nannofossil range chart with estimated calcareous nannofossil zones (Martini 1971). Other than Zone NP 9, all other calcareous nannofossil zones are approximated as the marker species for these zones are absent; discussion of the assemblages these estimates are based on is provided in the Supplementary Information. Grey boxes mark core gaps. Black triangles indicate location of chaotic, storm-influenced beds. 
clasts and only very small contributions of dinoflagellate cysts and pollen. Only one sample, at $\sim 153 \mathrm{~m}$, contains significant numbers of marine palynomorphs; these consist largely of the dinocyst genera Operculodinium, Spiniferites, Hafniasphaera, and Cordosphaeridium. The sample at $8.2 \mathrm{~m}$ contains mainly AOM, of a presumed dominantly marine origin due to the lack of structures assignable to components of terrestrial plants with high preservation potential, as well as increased amounts of terrestrial phytoclasts relative to the sample at $153 \mathrm{~m}$. The sample at $7.4 \mathrm{~m}$ is dominated by AOM, with few terrestrial phytoclasts. Two dinocysts were observed in this sample, both Polysphaeridium spp. Detailed palynological assemblages are shown in Supplementary Information Table S3.

\subsection{Bulk carbonate carbon and oxygen isotopes}

The bulk carbon isotope record (Fig. 6) of Core A can be split into two distinct intervals. Firstly, below $70 \mathrm{~m}$ the record is relatively stable, with $\delta^{13} \mathrm{C}$ values around $+3 \%$ comparable to the bulk carbonate record of other late Paleogene shallow water (Zhang et al. 2017) and deep water (Barnet et al. 2019) sites. Within this lower part of the record there are two long-term cycles (occurring over 100's of metres) in the carbon isotope record with an amplitude of $\sim 0.5-1 \%$. The first of these cycles runs from $380 \mathrm{~m}$ (the bottom of the core) to $200 \mathrm{~m}$, with values peaking at around $+3 \%$. The second cycle runs from $200 \mathrm{~m}$ to $\sim 50 \mathrm{~m}$, with values peaking at $+3.5 \%$ at $\sim 130 \mathrm{~m}$.

Between approximately $50 \mathrm{~m}$ and $46 \mathrm{~m}$ there is a carbon isotope excursion (CIE), with values dropping rapidly (within $4 \mathrm{~m}$ ) from $+3 \%$ to $+2 \%$ (Fig. 6). A core gap between 45-27 m cuts off a large section of the recorded carbon isotope record. The initial decrease in carbon isotope values occurs in the upper part of Zone SB 4 and between the Zones NP 9-11, suggesting this is the Paleocene-Eocene transition. Subsequent values from $27 \mathrm{~m}$ upwards are significantly more negative, with values from $0 \%$ to $-1 \%$ o recorded. These values occur in Zone NP 11, suggesting this part of the record is early Eocene in age.

The oxygen isotope record of Core A (Fig. 6) is characterised by values of approximately $-3.5 \%$ to

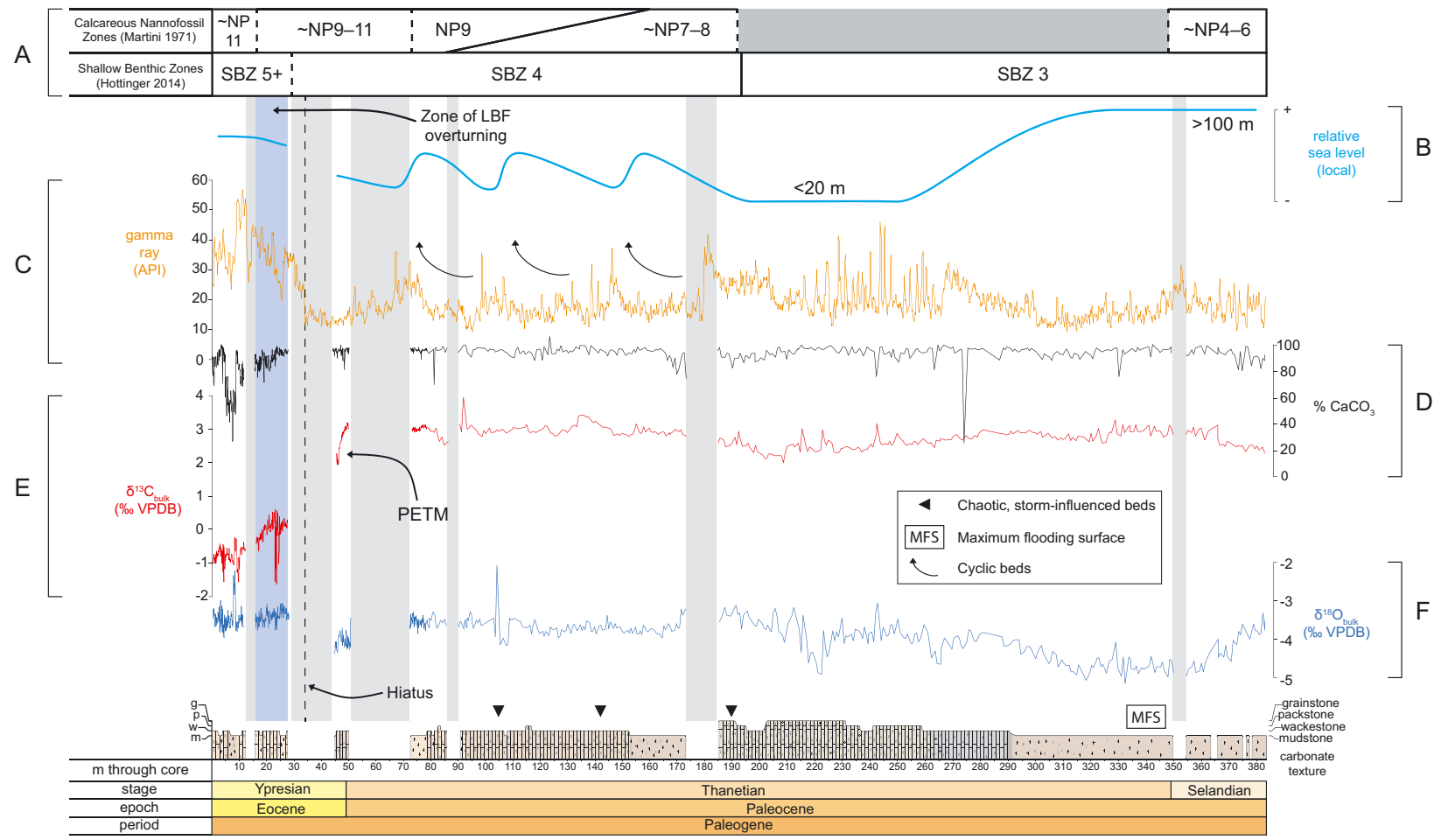

Fig. 6. $\mathbf{A}-\mathrm{SBZ}$ and estimated calcareous nannofossil zonations. B - Relative sea level curve derived from sedimentology and palaeoecology of faunal assemblages. $\mathbf{C}-$ Gamma ray data from wireline $\log$. $\mathbf{D}-\% \mathrm{CaCO}_{3}$. $\mathbf{E}-$ Bulk carbonate carbon isotopes. F - Bulk carbonate oxygen isotopes. Blue box depicts zone of turnover in LBF record. Grey boxes indicate core gaps. Dashed black line indicates possible location of hiatus/condensation, based on rapid increase on the gamma ray record. 
$-4.5 \%$. These values do not suggest that the core has been extensively diagenetically altered by interaction with meteoric water, whereby values would be much more negative (e.g., Knauth and Kennedy 2009, Ullmann and Korte 2015, Schobben et al. 2016). The cross-plot of pre-CIE $\delta^{13} \mathrm{C}$ vs. $\delta^{18} \mathrm{O}$ (Fig. S2) in which the $\mathrm{R}^{2}$ value of the data is low $\left(\mathrm{R}^{2}=0.0231\right)$, indicates that there is little correspondence between these data sets, further excluding a high degree of meteoric diagenesis. All the data also plot within values expected for a primary marine-derived carbonate (Arthur et al. 1983). In addition, cathodoluminescence analysis (Fig. S2) did not show the foraminifera or surrounding sediment to be luminescent, which would be an indication of possible alteration. $\mathrm{Mg} /$ $\mathrm{Ca}$ ratios from ICP-OES analysis are slightly higher than average values for a normal marine-derived carbonate (average Core A values of $35.6 \mathrm{mmol} /$ mol); however, this can be explained by the high abundance of echinoid fragments as seen in the LBF biostratigraphic log (Fig. 2) which have a naturally high $\mathrm{Mg} / \mathrm{Ca}$ ratio (Riechelmann et al. 2018, Ullmann et al. 2018). Shell remains of echinodermata typically rapidly recrystallise to low-Mg calcite, supplying excess $\mathrm{Mg}$ to diagenetic fluids which in turn would likely favour the formation of $\mathrm{Mg}$-enriched carbonate cements.

\subsection{Percentage calcium carbonate}

Percentage calcium carbonate values are generally very high and stable throughout the majority of the core, fluctuating between $\sim 80-100 \%$ (Fig. 6). There does not seem to be a close correspondence between described lithology as displayed in the sedimentary log and $\% \mathrm{CaCO}_{3}$, with all lithologies clearly dominated by carbonate phases regardless of texture and fossil content. There is a significant drop in average \% $\mathrm{CaCO}_{3}$ between $5-10 \mathrm{~m}$, with values reaching as low as $\sim 30 \%$, indicating a terrigenous fraction dominates the sedimentology towards the very top of the core.

\subsection{Gamma ray}

The gamma ray record shows a degree of variability, with values ranging from $\sim 10-55 \mathrm{API}$, but with most values between $\sim 10-40$ API through the majority of the core below $35 \mathrm{~m}$. Average values increase to $\sim 30-50$ API at the top of the core between $\sim 0-35 \mathrm{~m}$. There appears to be cyclicity in certain parts of the record, particularly between $\sim 180$ and $70 \mathrm{~m}$, where $\sim 3$ cycles can be visually identified with a wavelength of $\sim 30-40 \mathrm{~m}$ (Fig. 6). A sharp change in gamma ray values at $\sim 35 \mathrm{~m}$ suggests this may be the location of a hiatus.

\section{Discussion}

\subsection{An integrated age model for the late Paleocene to early Eocene of the central UAE}

LBF biostratigraphy (e.g., the SB Zone scheme) is critically important for providing age models in $\mathrm{Pa}-$ leogene-aged shallow water strata, which form extensive hydrocarbon reservoir rocks in the Middle East. Other marine taxa, such as calcareous nannofossils or planktonic foraminifera, are often absent due to differing environmental preferences. As a result of this mutual environmental exclusion of other taxa, it is often difficult to tie LBF biostratigraphy to global stratigraphy, which is key for correlating the stratigraphy of the deep and shallow water domains and for understanding responses to global climatic events. Exceptionally, in the new Core A section we have records of both LBF and calcareous nannofossil biostratigraphy from the same samples, as well as high resolution chemostratigraphy, which allows for correlation to global stratigraphy (Fig. 7).

In order to tie local and global, shallow and deep water stratigraphies together it is important to analyse variations in species ranges between localities. Improved knowledge of such discrepancies will allow for more precise and robust age models to be constructed based upon biostratigraphic horizons. In general the LBF assemblages in this study are in good agreement with other published literature from the Arabian Plate region (e. g., Pignatti et al. 1998, Serra-Kiel et al. 1998, Hottinger 2014) and are consistent with carbon isotope stratigraphies developed from deep sea records through this interval (Fig. 7 and Barnet et al. 2019). The broad trend, of more positive $\delta^{13} \mathrm{C}$ values in the late Paleocene and more negative values in the early Eocene, is coherent between the ODP Site 1262 reference section and the new Core A record, although there are discrepancies in the fine detail. Offsets in absolute values between the deep sea and shallow water bulk carbon isotope records (Fig. 7) may be influenced by the differing composition of biogenic carbonates in the shallow and deep sea (e. g., differing 
proportions of carbonate-secreting taxa), or differing isotopic compositions of the (bottom) waters due to the relative age and organic matter content of the water masses (Sluijs and Dickens 2012). Further to this, discrepancies in trends between the two bulk carbonate records could be due to a number of factors; for example the two sites are from different ocean basins (ODP Site 1262 is from the South Atlantic) and coeval carbon isotope records from different regions are rarely exactly the same due to differences in oceanic setting and productivity (e. g., Giusberti et al. 2007, Cramer et al. 2009, Westerhold et al. 2011, Slotnick et al. 2012, Agnini et al. 2016). The composition of the bulk material also differs, with ODP Site 1262 sediments composed of a nannofossil-foraminifera ooze with minimal diagenetic overprint, while Core A sediments are composed of both macro- and microfossil material with significant diagenetic cements in places. Finally, the two sites represent deposition at very different palaeodepths; Paleocene-Eocene-aged sediments at ODP Site 1262 were deposited at $\sim 3000-3500$ m water depth, while coeval sediments at Core A were deposited in $<100 \mathrm{~m}$ water depth. The potential differences in effects of burial and diagenesis in such different settings cannot be discounted. Alternative age models, based on tying the $\delta^{13} \mathrm{C}$ data between the sites more closely, yielded unrealistic sedimentation rates and do not agree with the LBF biostratigraphy of Core A, therefore they are not taken as the preferred option here (See Supplementary Information for further discussion and Figure S4).

The late Paleocene Zone SB 3-4 boundary within Core $\mathrm{A}$ is no younger than the calcareous nannofossil Zone NP 8 (Fig. 7). This agrees in general with the correlation in previous studies (Serra-Kiel et al. 1998, Scheibner et al. 2005) where the Zone SB 3-4 transition occurs at the end of Zone NP 8. However, results from this study place the Zone SB 3-4 boundary in the middle of Zones NP 7-8 rather than at the end (Fig. 7). Due to the uncertainty in the nannofossil stratigraphy at Core A, we consider this to be consistent with previous studies.

Previous studies from the Arabian Plate region (Serra-Kiel et al. 1998, Scheibner et al. 2005) place the Zone SB 4-5 boundary younger than Zone NP 8-9 boundary; however, in this study the Zone SB 4-5 boundary is located after the first occurrence of Discoaster multiradiatus (base of NP 9) and within the Zones NP 9-11. Some difficulties arise when positioning the Zone SB $4-5$ boundary primarily due to the occurrence of a hiatus/condensation in the sedimentary sequence (discussed below; Fig. 7). This problem is confounded by the lack of some Arabian Plate Eocene marker species and genera in the assemblage, such as the alveolinids (cf. Serra-Kiel et al. 1998, Scheibner and Speijer 2009). This could be due to Core A recording a relatively deeper shelf environment over this transition, indicated by the presence of Nummulites spp. and Assilina spp. which are thought to have resided below fair weather wave base (Racey 1995). The precise location of the Zone SB 4-5 transition, and its correlation to the calcareous nannofossil biozones, is important when discussing the PETM and the larger foraminifera turnover (LFT) event. Whether the LFT coincides with the PETM (Pujalte et al. 2009, Scheibner and Speijer 2009) or predates the PETM (Hottinger 1998, Zhang et al. 2013) is important for the applicability of the global stratigraphic horizon that the LFT creates, as well as the mechanisms driving the LFT. If, for example, the LFT denotes the Zone SB 4-5 transition, which in turn correlates to Zone NP 9, this creates a correlative surface across the breadth of Tethyan fauna as well as an easily recognisable change on which to base the biostratigraphy of the region. Results from this study suggest that the LFT event can be utilised to define the Zone SB 4-5 transition, which in turn correlates to calcareous nannofossil Zones NP 9-11 (Fig. 7).

Further to these potential discrepancies in biozone boundary correlations, the biostratigraphic ranges of some species at this site are different to those suggested in published literature (Fig. 8). In Core A the ranges of Lockhartia praehaimei, L. roeae, Kathina selveri, Dictyokathina simplex, Daviesina tenuis, and Thomasella labyrinthica extend to younger ages than previously recorded in literature from the Arabian Plate region (Pignatti et al. 1998, Serra-Kiel et al. 1998, Hottinger 2014). Miscellanea "rhomboidea" and Mardinella daviesi extend into older strata than currently recorded (Pignatti et al. 1998). Proposed expansions to these species biostratigraphic ranges are shown in Figure 8 . These differences in ranges of some species could be due to a number of reasons, for example, variability in local environmental conditions, diachroneity of speciation/extinction, or incomplete outcrop sections. Shallow, reef-associated LBF assemblages today are typically regionally heterogenous, with significant differences in the dominant taxa present (Hallock 1984, Hallock and Glenn 1986). This heterogeneity seems to be largely depth controlled, due to subsequent differences in light and nutrient availability, water energy, and substrate (Hottinger 1983). It is 


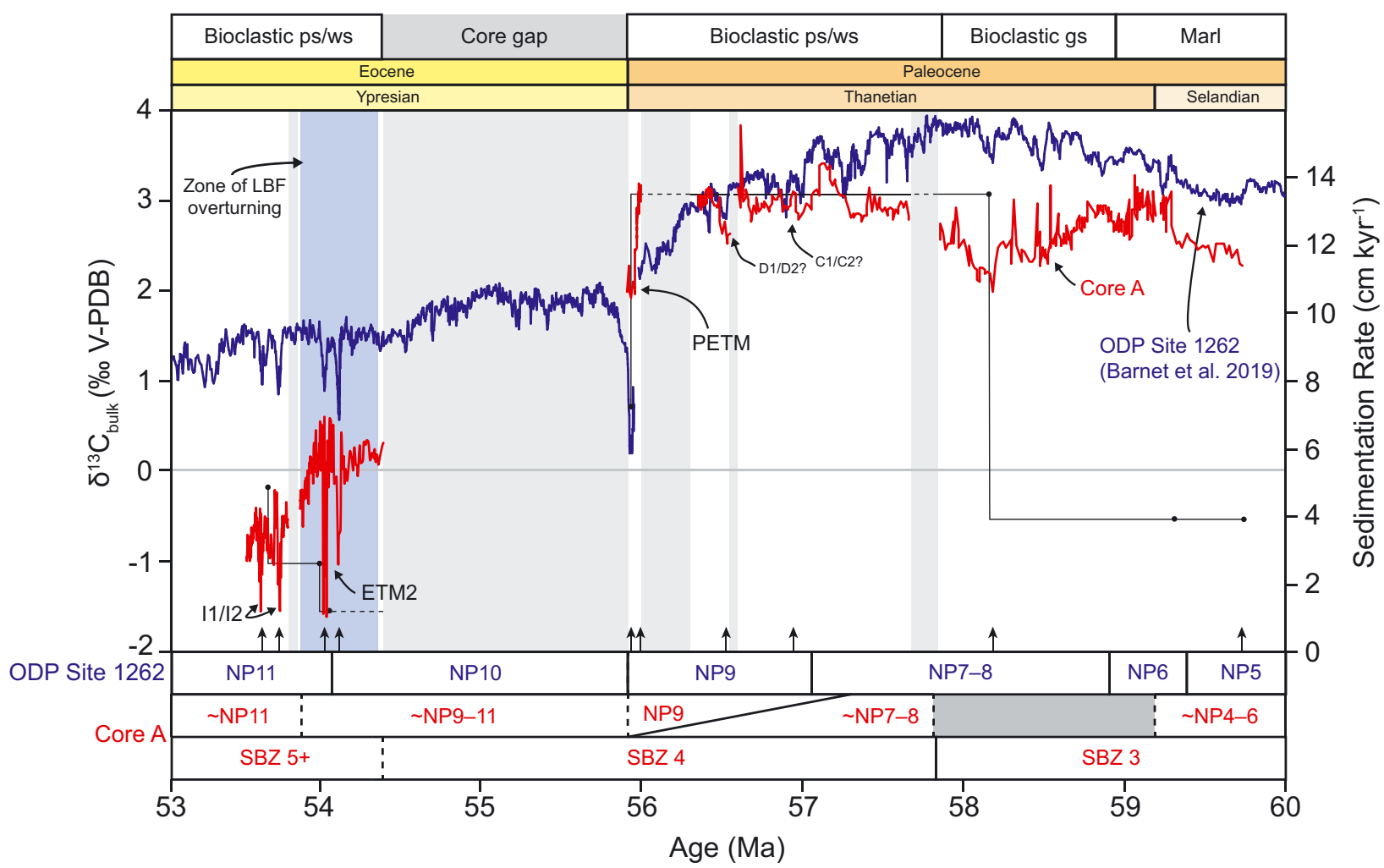

Fig. 7. Carbon isotope data from Core A (red) placed onto the latest orbitally-tuned age model by comparison to bulk carbon isotope data from South Atlantic ODP Site 1262 (blue; Barnet et al. 2019). Constraints from biostratigraphy (primarily calcareous nannofossils) and matching of characteristic shapes in the $\delta^{13} \mathrm{C}_{\text {bulk }}$ record have been used to tune the Core $\mathrm{A}$ record. Sedimentation rates are shown with black circles and solid/dashed black lines. Tie points used to create the age model are shown with vertical black arrows. For further details on tie points and construction of this age model see the Supplementary Information and Figure S4. The calcareous nannofossil zonations of both records are shown in red (Core A) and blue (Barnet et al. 2019), along with the Core A shallow benthic (SB) zonations. Core gaps are shown with grey boxes. Note the gap in data between $\sim 54.4$ to $\sim 55.8 \mathrm{Ma}$ (grey shaded area), which is partly the result of a coring gap in the Core A record, and partly the result of an apparently genuine hiatus/sedimentary condensation in this record. Potential hyperthermal events captured in the Core A record are annotated. Facies types are shown at the top of the figure: ps = packstone; ws = wackestone; gs = grainstone.

such spatial variability in LBF records that necessitates the application of integrated stratigraphic techniques and investigation of a range of localities.

All three stratigraphic indicators suggest there is a hiatus or sediment condensation in the core gap between $45-27 \mathrm{~m}$ (Fig. 7), as evidenced by missing biozones and the step change in carbon isotopes to significantly more negative values (Fig. 6). The core gap itself results in $\sim 1.4$ million years of strata missing, with the possible hiatus/condensation totalling an unknown amount of this time. The precise location of the hiatus within the core gap may be $\sim 34 \mathrm{~m}$, as denoted by the rapid increase in the (continuous) down-hole gamma ray values. Importantly, the initial drop in carbon isotopes ratios between $50-46 \mathrm{~m}$ occurs within a core section where there is no sedimentological evidence for a hiatus. This suggests we have captured one of the late Paleocene hyperthermal events, most likely the PETM CIE based upon reasonable estimates of sedimentation rates in such settings (Fig. S3) as well as the sedimentological and LBF biostratigraphic evidence (Fig. S4).

\subsection{Paleocene-Eocene palaeoenvironmental and biotic trends}

The late Paleocene sedimentary sequence preserved in Core A is indicative of a shallow $(<100 \mathrm{~m})$, low-energy, storm-dominated epeiric platform setting (Tucker and Wright 1990, Sharland et al. 2001) within the easternmost Paleogene Tethys Ocean (Fig. 1). Through the late Paleocene at this site there is a broad-scale change in the biotic assemblage, occurring across a number of 


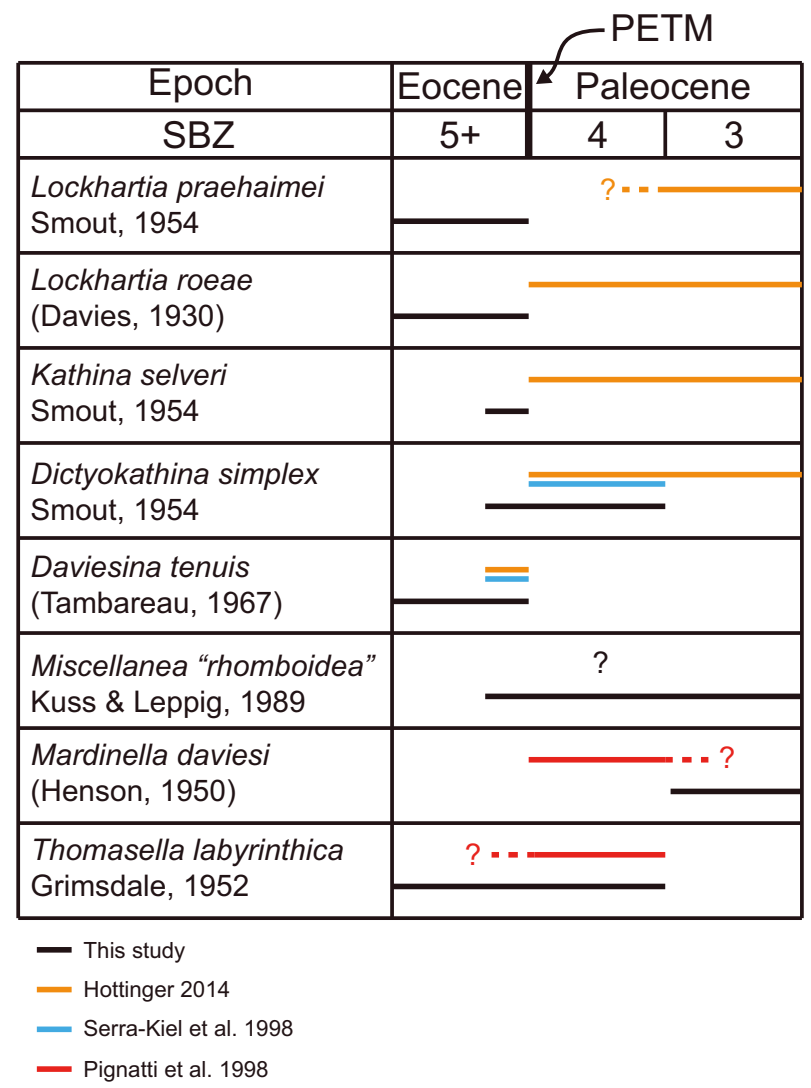

Fig. 8. Differences in biostratigraphic ranges between Core A and published literature.

genera, coupled to changing palaeoenvironmental settings. The lowermost facies $(383-285 \mathrm{~m})$ of marl is likely to represent a relatively deeper water (Fig. 6), low energy environment, below storm wave base, as indicated by the presence of thin-shelled bivalves and rare or absent photosynthetic organisms such as corals or LBF. This is interpreted as being locally representative of the regional maximum flooding surface recognised at $\sim 59.5 \mathrm{Ma}$ (re-calibrated to GTS2012; Fig. 6; Sharland et al. 2001, Haq and Al-Qahtani 2005). The Core A record has been correlated to the latest orbitally tuned age model from Ocean Drilling Program (ODP) Site 1262 (Fig. 7 and Supplementary Information; Barnet et al. 2019), using the carbon isotope records and biostratigraphy from both sites. Sedimentation rates at Core A can be estimated (Fig. S3), and through this interval they are among the lowest in the record $\left(\sim 3.9 \mathrm{~cm} \mathrm{kyr}^{-1}\right)$, which agrees well with the observed sedimentological sequence.

As the shallower water facies prograded over these deeper water sediments, shallow water fauna including solitary corals, gastropods, bivalves, and LBF became abundant $(\sim 260-185 \mathrm{~m})$. This fauna represents a diverse shallow water reef assemblage, a highly productive "carbonate factory" likely deposited at $<15 \mathrm{~m}$ water depth (cf. Tucker and Wright 1990). Sedimentation rates through this time increase significantly up to $\sim 13.5 \mathrm{~cm} \mathrm{kyr}^{-1}$ (Figs. 7 and S3). This is interpreted as the Arabian Plate carbonate platform prograding out into the adjacent deeper water Muthaymimah Trough sub-basin to the north-east (Fig. 1B). Progradation occurs due to rapid subsidence in this region during the early Paleogene initiated by the cessation of Semail ophiolite obduction to the east (Ziegler 2001). This rapid tectonic deepening is also enhanced by eustasy (Sharland et al. 2001). As the carbonate platform filled the available accommodation space, with inferred accelerating carbonate production, an overall shallowing-up sequence is observed. From $\sim 173 \mathrm{~m}$ upwards a series of cyclic shallowing-up parasequences are observed in both the sedimentology and the gamma ray signal (Fig. 6). Three cycles can be observed in the record with a wavelength of $\sim 30-40 \mathrm{~m}$. The top of each parasequence is marked by a chaotic, storm-influenced bed with broken bioclasts (Figs. 2 and Fig. 6), due to a relative decrease in sea level, bringing Core A to above storm-wave base, suggesting these may be a series of $4^{\text {th }}$ order sea level cycles. From the orbitally tuned age model (Fig. 7) these cycles cover $\sim 57.6 \mathrm{Ma}$ to $56.3 \mathrm{Ma}$, a period of approximately $1.3 \mathrm{Myr}$, making these cycles roughly $400 \mathrm{kyr}$ in duration. As such, these cycles could reflect the long eccentricity (405 kyr) cycle. High-resolution orbitally tuned stable isotope records from the late Paleocene of the South Atlantic (Zachos et al. 2010, Littler et al. 2014, Barnet et al. 2019) and Pacific Ocean (Westerhold et al. 2008) show long eccentricity as the dominant frequency expressed in both climate and carbon-cycle records.

From $\sim 152 \mathrm{~m}$ upwards in the core there is the systematic loss of corals and gastropods (Fig. 2). This gradual transition through the core, with the loss of the diverse biotic assemblage but increases in LBF diversity, suggests that the environment became more favourable to the rapidly calcifying LBF (Scheibner et al. 2005). This could be forced by a number of factors, such as an increase in nutrient input disturbing the previously stable oligotrophic environment and creating a more meso- to eutrophic environment (Scheibner and Speijer 2008b, Zamagni et al. 2008), or increases in $p \mathrm{CO}_{2}$ through this interval adversely affecting the growth of calcareous macroorganisms (Shirayama and Thornton 2005). Alternatively, this gradual change could be due to an overall 
deepening in the sequence, losing the diverse fauna present on the reef and moving towards an open shelf setting (Hallock and Glenn 1986). This latter hypothesis is supported for the upper part of the core, after the core gap (Fig. 2), by the presence of generally deeper dwelling nummulitids (Racey 1995).

\subsubsection{The Paleocene-Eocene transition}

The partial record of the PETM onset recovered within Core A spans $\sim 4 \mathrm{~m}$ of stratigraphy and is therefore relatively expanded compared to many other PETM records from deeper water sites. Such expanded PETM sections have also been recorded in other marginal marine sites, such as Svalbard (Cui et al. 2010), the New Jersey margin (Zachos et al. 2006, Sluijs et al. 2007, Kopp et al. 2009), the Northern Tethys (Giusberti et al. 2007), and Tibet (Zhang et al. 2017). Unlike deep sea records, this very shallow marine $(\sim<20 \mathrm{~m}$ water depth) environment is unaffected by shoaling of the carbonate compensation depth (CCD). Over the expanded section of the PETM onset, high resolution sample intervals (approximately every $\sim 0.8 \mathrm{~m}$; Fig. 2 ) allow us to assess changes in the LBF assemblage during this interval. Despite a major perturbation to the carbon cycle shown by the rapid decline in carbon isotope values (Fig. 6) the LBF assemblage is stable throughout this $4 \mathrm{~m}$ of stratigraphy (Fig. 2), with 9 of the 11 species present in the latest Paleocene also present after the Paleocene-Eocene boundary. The two exceptions are Discocyclina sp. and Miscellanea sp., with last occurrences at $\sim 47 \mathrm{~m}$; however, as this is the start of the coring gap it could be that the continued record of these genera has not been captured.

Above the hiatus/condensation in sedimentary deposition, occurring in the core gap between 45-27 m (Fig. 6; likely $\sim 34 \mathrm{~m}$ ), the sediments are likely within Zone NP 11, correlating to the early Eocene. After the core gap, carbon isotope values decrease further from $0 \%$ to $-1 \%$. These values, therefore, likely represent the decline towards the early Eocene climatic optimum (EECO; 52-50 Ma), the peak of Paleogene warmth (Zachos et al. 2001, 2008, Cramwinckel et al. 2018). Prior to the EECO there are a number of orbitally paced hyperthermal events observed in the carbon isotope record, on the order of -1\% (Cramer et al. 2003, Zachos et al. 2010, Littler et al. 2014, Barnet et al. 2019). Within the Core A record there are three CIEs stratigraphically above $27 \mathrm{~m}$. These occur at $23 \mathrm{~m}$, $10 \mathrm{~m}$, and $4 \mathrm{~m}$ and are $-1.5 \%,-1 \%$ and $-0.8 \%$ in magnitude, respectively. Located within Zones NP
9-11, it is likely that these negative excursions are expressions of hyperthermal events, such as Eocene thermal maximum 2 (ETM-2 at $\sim 53.7 \mathrm{Ma}$; Lourens et al. 2005, Stap et al. 2010). As with the PETM interval at this site, there would be no expected dissolution during these events due to the shallow shelf setting located far above the CCD. Calculated sedimentation rates here fit with this interpretation; approximate average rates of $2.9 \mathrm{~cm} \mathrm{kyr}^{-1}$ at the top of the core (Figs. 7 and S3) would equate to the top $27 \mathrm{~m}$ the core covering a $\sim 925 \mathrm{kyr}$ period from $\sim 54.4 \mathrm{Ma}$, which is the time period and scale on which these hyperthermals occur (Barnet et al. 2019).

There is no increase in gamma ray values throughout the putative PETM interval (Fig. 6), commensurate with the LBF evidence for a relatively stable local environment during this time. However, there is a significant increase in gamma ray values after the hiatus/sedimentary condensation $(\sim 30 \mathrm{~m})$ within the coring gap and into the early Eocene (Fig. 6). As gamma ray values represent the combined abundance of radioactive $\mathrm{K}, \mathrm{U}$ and $\mathrm{Th}$, an increase is indicative of either an increase in organic matter within the sediments, or of increasing clay content in the core (Bigelow 2002), both of which can contain incorporated radioactive elements. There is no evidence for glauconite in the core, which can also elevate total gamma ray values through elevated $\mathrm{K}$ content (e. g., Hesselbo 1996). The $\% \mathrm{CaCO}_{3}$ values through this interval also decrease (Fig. 6), potentially due to dilution from increased terrigenous input (Slotnick et al. 2012). Taken together, these trends suggest that through the early Eocene interval prior to the EECO, there may have been increased humidity and/or rainfall in this part of the Arabian Peninsula. This humidity could have caused either enhanced input of riverine transported clay material derived from the areas of emergence to the east and west of the Core A locality (Fig. 1), and/or elevated organic matter burial through increased nutrient-driven algal productivity potentially coupled with increased anoxia. The former argument is supported by the increase in abundance of terrestrially derived phytoclasts, most likely dominantly river transported, in the sediments during the early Eocene ( $\sim 8 \mathrm{~m}$; Table S3) relative to the late Paleocene (Hollis et al. 2005, Slotnick et al. 2012). Calculated sedimentation rates through this interval also show an increase from $\sim 1.2$ to $5 \mathrm{~cm} \mathrm{kyr}^{-1}$ (Fig. S3), which is consistent with elevated terrestrial input in this setting. This matches trends seen in open ocean sites, such as ODP Site 1262 in the South Atlantic 
(Barnet et al. 2019), and shelf sites, such as Mead Stream in New Zealand (Slotnick et al. 2012), where sedimentation rates also show an increase into the Eocene.

\subsection{Response of shallow marine biota to Eocene warmth}

Following the PETM CIE there is a gradual turnover in the LBF assemblage at Core A, within a broadly consistent lithology suggesting the depositional environment is largely unchanging. The larger foraminifera turnover (LFT) event is preceded by a major perturbation to the carbon cycle and elevated terrestrial input to the Core A site. Despite these perturbations to the environment, during the PETM onset the LBF assemblage is stable (Fig. 2), with the turnover occurring later in the early Eocene. This suggests long-term warming into the early Eocene may have been the trigger for the LFT, rather than the PETM itself. From $\sim 27 \mathrm{~m}$ to $\sim 16 \mathrm{~m}$, above the core gap, there is a stepchange in the assemblage, with an increased dominance of less-specialised and smaller fauna that are better able to inhabit/colonise perturbed environments, and/or are more tolerant to a wider range of oceanographic conditions. Examples of such genera include Rotalia spp. and Sakesaria spp. (Fig. 2). Through the early Eocene interval there is also an increase in the genera and species richness of the LBF assemblage. One way to facilitate increases in species diversity is known in modern ecology as the intermediate disturbance hypothesis (IDH). The IDH theory suggests that when there is increasing ecological disturbance to an environment there may also be increasing species diversity (Townsend et al. 1997). Once an intermediate level of disturbance is reached both rapid opportunistic colonisers and species which are more competitive are able to co-occur (Townsend et al. 1997). The changes observed in the Core A LBF assemblage, from
27-16 m, could therefore be due to an intermediate level of disturbance to the environment having been reached, creating a "sweet spot" for increased biodiversity. This increase in genera and species richness over the Paleocene-Eocene interval is also seen in other areas of the shallow Tethys Ocean (Scheibner and Speijer 2008b). Known as the Lockhartia Sea (Hottinger 2014), this was a biogeographic region defined by increased generic diversity in "hot spots" (geographic regions of maximum biodiversity in a given time interval) which migrate around the Paleogene Tethys Ocean (Fig. 9; Renema et al. 2008, Hottinger 2014). Prior to the PETM, the environment was characterised by stable, low-diversity conditions, as demonstrated by the relatively unchanging sediments (Fig. 2), LBF assemblage, and the dominance of Cibicides spp. in the smaller benthic foraminiferal assemblage (Boscolo-Galazzo, pers. comm.). The disturbance to the ecosystem precipitated by the PETM, and likely continuing into the early Eocene (section above the core gap) may have triggered the concurrent increase in diversity and dominance of LBF.

A number of studies have measured LBF diversity or species richness on or near the Arabian Plate during the Paleogene; however, estimates of generic and specific level diversity vary across locations (Table 1). In the mid to late Paleocene the number of LBF genera in Oman was shown to be $\mathrm{n}=8$ (Serra-Kiel et al. 2016a), increasing to $\mathrm{n}=18$ in the mid-Eocene (SerraKiel et al. 2016b). In the nearby offshore India province the number of species/morphotypes in the Eocene was measured at $\mathrm{n}=29$, with this significantly decreasing to $n=2$ in the Oligocene, although few Oligocene samples were available (Cotton et al. 2019). Contrary to these estimates Renema et al. (2008) suggest that the number of genera in the south-eastern Arabian Plate was as low as $n=5-8$ in the mid Eocene, increasing to its maximum of $\mathrm{n}=9-12$ in the Miocene. This study suggests that the modern hotspot in the

Table 1. Summary table of changes in LBF specific- and generic-level diversity changes through time described in the text.

\begin{tabular}{llll}
\hline Location & Number of genera/species & Approximate age & Reference \\
\hline Oman & 8 genera & Mid to late Paleocene & Serra-Kiel et al. 2016a \\
UAE & 9 genera, 9 species & Late Paleocene & This study \\
UAE & 11 genera, 16 species & Early Eocene & This study \\
Oman & 18 genera & Mid Eocene & Serra-Kiel et al. 2016b \\
South east Arabian Plate & $5-8$ genera & Mid Eocene & Renema et al. 2008 \\
Western India & 29 species & Eocene & Cotton et al. 2019 \\
Western India & 2 species & Oligocene & Cotton et al. 2019 \\
South east Arabian Plate & $9-12$ genera & Miocene & Renema et al. 2008 \\
\hline
\end{tabular}




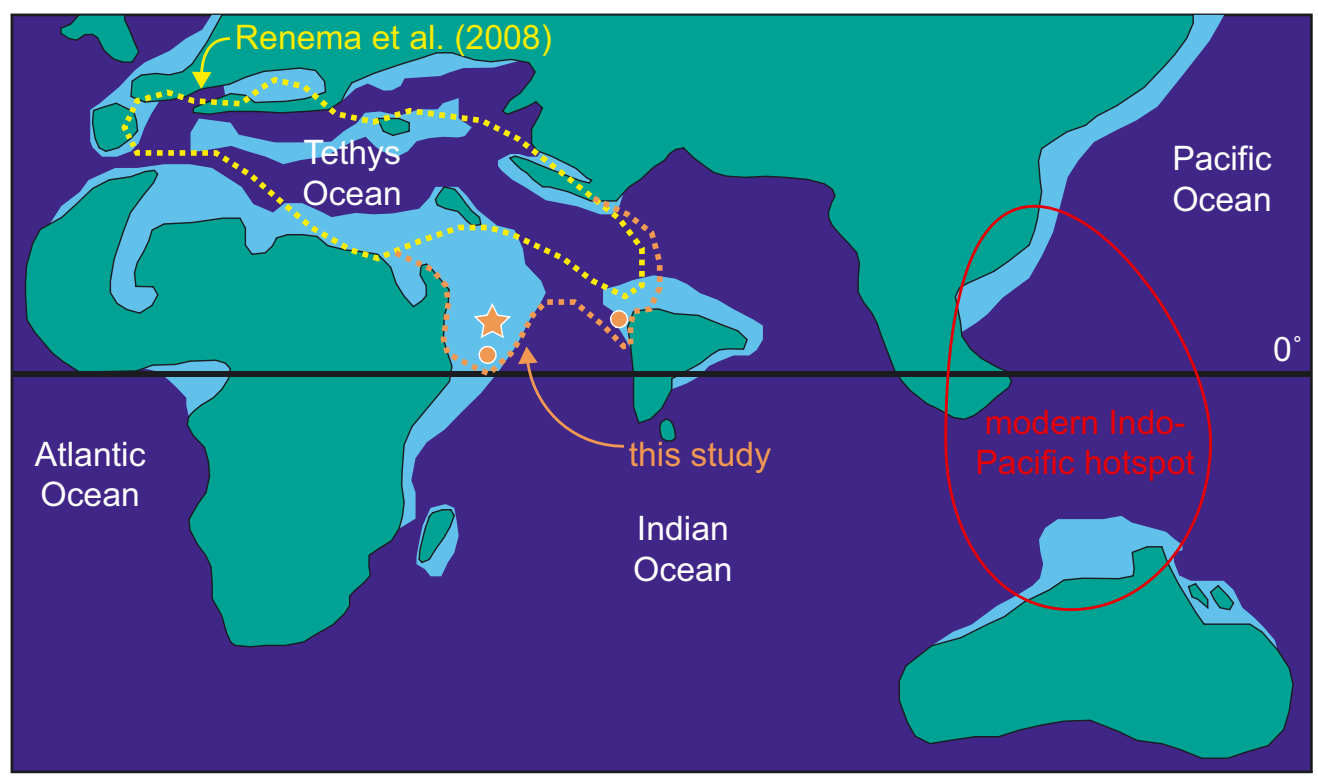

Fig. 9. Figure adapted from Renema et al. (2008) to demonstrate the extensions of the proposed hotspots through the early-middle Eocene. Yellow dashed area denotes the middle Eocene hotspot from Renema et al. (2008), orange dashed area denotes extension of this hotspot in the early Eocene from this study (orange star) and others (orange circles: Serra-Kiel et al. 2016a, Cotton et al. 2019). Red solid line indicates area of modern hotspot in the Indo-Pacific (Renema et al. 2008).

Indo-Pacific region evolved due to the eastward movement of generic level alpha biodiversity (number of genera in a single location) from the Tethys in the middle Eocene (Fig. 9 and Renema et al. 2008). Our data from the UAE suggests that the increase in generic and species richness in this region actually began as early as the early Eocene (Fig. 9), which is in agreement with other more recent studies from the broader region (Serra-Kiel et al. 2016b, Cotton et al. 2019). It has been suggested that changes in tectonic configuration of continents, creating and destroying numerous shallow water habitats, is the main driving force behind these changes in biodiversity (Renema et al. 2008). However, the timing of these biodiversity increases, coincident with or following on from the PETM both in this study and others, suggests that early Eocene climate could have been a contributing factor in the upward trajectory of biodiversity (Orue-Etxebarria et al. 2001, Pujalte et al. 2009, Scheibner and Speijer 2009).

\subsection{The early Paleogene vs anthropogenic climate change in the shallow water realm}

The results of this study suggest that the shallow water LBF community was able to turnover and subsequently thrive throughout the extreme warming ex- perienced over the early Eocene, becoming the dominant shallow water carbonate producers of the Eocene (Scheibner and Speijer 2008a, Afzal et al. 2011, Zamagni et al. 2012). There are, therefore, implications for the future of shallow water environments with continued anthropogenic climate change and ocean acidification. For example, will there be a shift of the dominant carbonate producers? Will modern coral reefs be replaced by a diverse fauna of LBF? Larger foraminifera at present produce $2.5 \%$ of the total $\mathrm{CaCO}_{3}$ in the oceans (Langer 2008), they are therefore important for the global climate-carbon cycle and constitute a substantial carbon sink in the shallow oceans.

Short-term (maximum 6 weeks) lab experiments suggest that LBF are unaffected by $\mathrm{pH}$ decrease (acidification) and temperature increase, in some cases even displaying an increase in growth yields under these conditions (Hikami et al. 2011, Vogel and Uthicke 2012, Prazeres et al. 2015). On the longterm, however, the effects are markedly different. In both lab and field experiments long-term changes to $\mathrm{pH}$ or temperature had major negative effects upon the LBF communities, with the highest impact observed in lab experiments when temperature increase and acidification acted in unison (Schmidt et al. 2014). Alternatively, in field studies conducted on shallow benthic communities close to volcanic $\mathrm{CO}_{2}$ seeps indicate an 
inability to tolerate $\mathrm{pH}<7.9$. At current rates of $\mathrm{CO}_{2}$ injection into the atmosphere, this suggests that ocean acidification will reach a threshold of major extinctions in the shallow water benthos community by 2100 (Uthicke et al. 2013). Over this long-term, coral reefs also show major disruption as a result of acidification and increased temperatures (Fabricius et al. 2011), similar to the negative effects observed in the Paleocene (Scheibner and Speijer 2008a). Ultimately, this comparison shows us that rate of change is likely key when assessing the ability for shallow water benthos to adapt. However, with anthropogenic climate change being orders of magnitude faster than changes that occurred during the early Eocene or even the PETM, it is problematic to use the two as direct analogues for the near future.

\section{Conclusions}

Integrated LBF and calcareous nannofossil biostratigraphy and carbonate stable isotope chemostratigraphy from this easternmost Tethyan site show a stepwise shift in palaeoenvironment from the late Paleocene into the early Eocene. The Paleocene strata in this region record a relatively stable time period in terms of climate, oceanography, and palaeoenvironmental setting, allowing a diverse shallow water $(<100 \mathrm{~m})$ biotic assemblage to thrive through the late Paleocene. The local response to globally warmer temperatures during the Paleocene to Eocene involved the systematic loss of corals, gastropods, and bivalves. Further to this, the LBF assemblage underwent turnover in the early Eocene, with smaller and less specialised genera such as Rotalia spp. and Sakesaria spp. outcompeting the previously dominant Paleogene genera (Figs. 2 and 6 ). It is hypothesised that the perturbations to ocean and atmosphere temperature, the carbon cycle, run-off, and nutrient input through the early Eocene were the trigger for an increase in generic and specific level diversity at this site and others in the eastern Tethys Ocean. This was the beginning of the generic biodiversity hotspot that developed through the Paleogene and Neogene in the Tethys, moving eastwards to its present-day hotspot in the Indo-Pacific (Fig. 9). Despite the success of the larger benthic community through this major palaeoclimatic change, they do not appear to be resilient to anthropogenic climate change. It is likely that the significantly faster rate of change in $\mathrm{pH}$ and temperature at the present, compared to the Paleocene-Eocene, is the explanation; however, the vastly different timescale lengths these studies are conducted on does not allow for a more definite conclusion.

With an integrated record of biostratigraphy and chemostratigraphy from this region it is possible to tie a local, shallow water record to global stratigraphy through the early Paleogene interval. This record suggests that the LFT event can be correlated to Zone SB 5. This stratigraphic interval, recorded in the shallow water domain, can be tied to calcareous nannofossil Zones NP 9-11. These integrated records allow for the correlation of the shallow and deep water domains and provide important and easily recognisable stratigraphic horizons which tie directly to a bioand chemostratigraphic age model.

Acknowledgements. We would like to thank Flavia Boscolo-Galazzo, Johannes Pignatti and Cesare Papazzoni for providing expertise and advice when identifying the smaller benthic and larger benthic foraminifera assemblages and for their further input on the ecological significance of the assemblages. We also thank Steve Pendray for preparing petrological thin sections. We are very appreciative of the two anonymous reviewers who helped to improve the manuscript with detailed comments. We acknowledge Abu Dhabi National Oil Company (ADNOC) for access to core material and permission to publish data based upon interpretations and analysis of this material. The research contained in this publication contains work conducted during a PhD study undertaken as part of the Natural Environment Research Council (NERC) Centre for Doctoral Training in Oil \& Gas (grant number NE/M00578X/1) and is fully funded by NERC whose support is gratefully acknowledged. AS thanks the European Research Council for Consolidator Grant 771497.

\section{References}

Adams, A.E., MacKenzie, W.S., 1998. Cathodoluminescence. In: Adams, A. E., MacKenzie, W. S. (Eds.), A Colour Atlas of Carbonate Sediments and Rocks Under the Microscope, Manson Publishing, London, 101-156.

Afzal, J., Williams, M., Leng, M. J., Aldridge, R. J., 2011. Dynamic response of the shallow marine benthic ecosystem to regional and pan-Tethyan environmental change at the Paleocene-Eocene boundary. Palaeogeography, Palaeoclimatology, Palaeoecology 309, 141-160.

Afzal, J., Williams, M., Leng, M. J., Aldridge, R. J., Stephenson, M.H., 2010. Evolution of Paleocene to Early Eocene larger benthic foraminifer assemblages of the Indus Basin, Pakistan. Lethaia 44, 299-320.

Agnini, C., Fornaciari, E., Raffi, I., Catanzariti, R., Pälike, H., Backman, J., Rio, D., 2014. Biozonation and biochronology of Paleogene calcareous nannofossils from 
low and middle latitudes. Newsletters on Stratigraphy 47 (2), 131-181.

Agnini, C., Fornaciari, E., Raffi, I., Rio, D., Röhl, U., Westerhold, T., 2007. High-resolution nannofossil biochronology of middle Paleocene to early Eocene at ODP Site 1262: Implications for calcareous nannoplankton evolution. Marine Micropalaeontology 64 (3), 215-248.

Agnini, C., Macri, P., Backman, J., Brinkhuis, H., Fornaciari, E., Giusberti, L., Luciani, V., Rio, D., Sluijs, A., Speranza, F., 2009. An early Eocene carbon cycle perturbation at $\sim 52.5 \mathrm{Ma}$ in the Southern Alps: Chronology and biotic response. Paleoceanography 24 (2), 1-14.

Alegret, L., Ortiz, S., 2006. Global extinction event in benthic foraminifera across the Paleocene/Eocene boundary at the Dababiya stratotype section. Micropaleontology 52 (5), 433-447.

Alsharhan, A.S., Nairn, A.E. M., 1995. Tertiary of the Arabian Gulf: sedimentology and hydrocarbon potential. Palaeogeography, Palaeoclimatology, Palaeoecology 114 (2-4), 369-384.

Anagnostou, E., John, E.H., Edgar, K. M., Foster, G. L., Ridgwell, A., Inglis, G. N., Pancost, R. D., Lunt, D. J., Pearson, P. N., 2016. Changing atmospheric $\mathrm{CO}_{2}$ concentration was the primary driver of early Cenozoic climate. Nature 533 (7603), 380-384.

Arthur, M. A., Anderson, T. F., Kaplan, I. R., Veizer, J., Land, L. S., 1983. Stable isotopes in oxygen and carbon and their application to sedimentologic and paleoenvironmental problems. In: Arthur, M. A. (Ed.), Stable Isotopes in Sedimentary Geology. SEPM Short Course No. 10, Dallas, $p$.

Aze, T., Pearson, P. N., Dickson, A. J., Badger, M.P.S., Bown, P. R., Pancost, R. D., Gibbs, S. J., Huber, B. T., Leng, M. J., Coe, A. L., Cohen, A. S., Foster, G. L., 2014. Extreme warming of tropical waters during the Paleocene-Eocene thermal maximum. Geology 42 (9), 739-742.

Bains, S., Corfield, R. M., Norris, R. D., 1999. Mechanisms of climate warming at the end of the Paleocene. Science 285, 724-727.

Barnet, J. S. K., Littler, K., Westerhold, T., Kroon, D., Leng, M. J., Bailey, I., Röhl, U., Zachos, J. C., 2019. A HighFidelity Benthic Stable Isotope Record of Late Cretaceous-Early Eocene Climate Change and CarbonCycling. Paleoceanography and Paleoclimatology 34, $1-20$.

Beavington-Penney, S. J., Wright, V. P., Racey, A., 2006. The middle Eocene Seeb Formation of Oman: An investigation of acyclicity, stratigraphic completeness, and accumulation rates in shallow marine carbonate settings. Journal of Sedimentary Research 76 (9-10), 1137-1161.

Bigelow, E.L., 2002. Wireline Log Measurements and Supportive Information. In: Bigelow, E. L. (Ed.), Introduction to Wireline Log Analysis. Baker Atlas, Baker Hughes, 43-84.

Bijl, P. K., Schouten, S., Sluijs, A., Reichart, G.-J., Zachos, J. C., Brinkhuis, H., 2009. Early Palaeogene temperature evolution of the southwest Pacific Ocean. Nature Letters 461, 776-779.
Bolle, M.P., Adatte, T., 2001. Palaeocene-early Eocene climatic evolution in the Tethyan realm: clay mineral evidence. Clay Minerals 36 (2), 249-261.

Bolle, M.P., Pardo, A., Hinrichs, K.-U., Adatte, T., Von Salis, K., Burns, S., Keller, G., Muzylev, N., 2000. The Paleocene-Eocene transition in the marginal northeastern Tethys (Kazakhstan and Uzbekistan). International Journal of Earth Sciences 89, 390-414.

BouDagher-Fadel, M. K., 2008. The Cenozoic larger benthic foraminifera: the Palaeogene. In: Wignall, P. B. (Ed.), Evolution and Geological Significance of the Larger Benthic Foraminifera, Elsevier, Amsterdam, 297-419.

Bowen, G. J., Beerling, D. J., Koch, P. L., Zachos, J.C., Quattlebaum, T., 2004. A humid climate state during the Palaeocene/Eocene thermal maximum. Nature 432, 495-499.

Bowen, G. J., Bowen, B. B., 2008. Mechanisms of PETM global change constrained by a new record from central Utah. Geology 36 (5), 379-382.

Bown, P. R., Dunkley-Jones, T., 2012. Calcareous nannofossils from the Paleogene equatorial Pacific (IODP Expedition 320 Sites U1331-U1334). Journal of Nannoplankton Research 32, 3-51.

Bown, P. R., Newsam, C., 2017. Calcareous nannofossils from the Eocene North Atlantic Ocean (IODP Expedition 342 Sites U1403-U1411). Journal of Nannoplankton Research 37, 25-60.

Bown, P. R., Young, J. R., 1998. Techniques. In: Bown, P. R. (Ed.), Calcareous Nannofossil Biostratigraphy. British Micropalaeontological Society Publication Series, Kluwer Academic, London, 16-28.

Carmichael, M.J., Inglis, G. N., Badger, M.P. S., Naafs, B. D. A., Behrooz, L., Remmelzwaal, S., Monteiro, F. M., Rohrssen, M., Farnsworth, A., Buss, H. L., Dickson, A. J., Valdes, P. J., Lunt, D. J., Pancost, R. D., 2017. Hydrological and associated biogeochemical consequences of rapid global warming during the Paleocene-Eocene Thermal Maximum. Global and Planetary Change 157, 114-138.

Charisi, S. D., Schmitz, B., 1998. Paleocene to early Eocene paleoceanography of the Middle East: The $\delta^{13} \mathrm{C}$ and $\delta^{18} \mathrm{O}$ isotopes from foraminiferal calcite. Paleoceanography 13 (1), 106-118.

Clemens, S. C., Kuhnt, W., LeVay, L. J., Anand, P., Ando, T., Bartol, M., Bolton, C. T., Ding, X., Gariboldi, K., Giosan, L., Hathorne, E.C., Huang, Y., Jaiswal, P., Kim, S., Kirkpatrick, J.B., Littler, K., Marino, G., Martinez, P., Naik, D., Peketi, A., Phillips, S.C., Robinson, M. M., Romero, O.E., Sagar, N., Taladay, K. B., Taylor, S. N., Thirumalai, K., Uramoto, G., Usui, Y., Wang, J., Yamamoto, M., Zhou, L., 2016. Expedition 353 methods. In: Clemens, S. C., Kuhnt, W., LeVay, L. J., the Expedition 353 Scientists (Eds.), Indian Monsoon Rainfall. Proceedings of the International Ocean Discovery Program, 353. College Station, TX (International Ocean Discovery Program).

Cohen, A.S., Coe, A.L., Kemp, D. B., 2007. The Late Palaeocene-Early Eocene and Toarcian (Early Jurassic) carbon isotope excursions: A comparison of their time 
scales, associated environmental changes, causes and consequences. Journal of the Geological Society, London 164, 1093-1108.

Cotton, L. J., Wright, V. P., Barnett, A., Renema, W., 2019. Larger benthic foraminifera from the Panna and Mukta fields offshore India: Paleobiogeographic implications. Journal of Foraminiferal Research 49 (3), 243-258.

Coxall, H.K., Pearson, P., 2007. The Eocene-Oligocene Transition. In: Williams, M., Haywood, A. M., Gregory, F. J., Schmidt, D. N. (Eds.), Deep-Time Perspectives on Climate Change: Marrying the Signal from Computer Models and Biological Proxies. . The Micropalaeontological Society, Special Publications. The Geological Society, London, 351-387.

Cramer, B. S., Wright, J. D., Kent, D. V., Aubry, M. P., 2003. Orbital climate forcing of $\delta^{13} \mathrm{C}$ excursions in the late Paleocene-early Eocene (chrons C24n-C25n). Paleoceanography 18 (4), 1-25.

Cramwinckel, M. J., Huber, M., Kocken, I. J., Agnini, C., Bijl, P. K., Bohaty, S. M., Frieling, J., Goldner, A., Hilgen, F. J., Kip, E. L., Peterse, F., Ploeg, R. V.D., Röhl, U., Schouten, S., Sluijs, A., 2018. Synchronous tropical and polar temperature evolution in the Eocene. Nature Letters 559, 383-386.

Cui, Y., Kump, L.R., Ridgwell, A. J., Diefendorf, A.F., Junium, C.K., 2010. A high-resolution record from Svalbard of carbon release during the Paleocene-Eocene Thermal Maximum. Journal of Earth Science Special Issue 21, 190.

Cui, Y., Kump, L. R., Ridgwell, A. J., Charles, A. J., Junium, C.K., Diefendorf, A. F., Freeman, K. H., Urban, N. M., Harding, I. C., 2011. Slow release of fossil carbon during the Palaeocene-Eocene Thermal Maximum. Nature Geoscience 4, 481-485.

Dickens, G. R., Castillo, M. M., Walker, J.C. G., 1997. A blast of gas in the latest Paleocene: Simulating first-order effects of massive dissociation of oceanic methane hydrate. Geology 25 (3), 259-262.

Dickens, G. R., Neil, J. R. O., Rea, D. K., Owen, R. M., 1995. Dissociation of oceanic methane hydrate as a cause of the carbon isotope excursion at the end of the Paleocene. Paleoceanography 10 (6), 965-971.

Dickson, A. J., Cohen, A. S., Coe, A. L., Davies, M., Shcherbinina, E. A., Gavrilov, Y. O., 2015. Evidence for weathering and volcanism during the PETM from Arctic Ocean and Peri-Tethys osmium isotope records. Palaeogeography, Palaeoclimatology, Palaeoecology 438, 300-307.

Dill, H. G., Wehner, H., Kus, J., Botz, R., Berner, Z., Stüben, D., Al-Sayigh, A., 2007. The Eocene Rusayl Formation, Oman, carbonaceous rocks in calcareous shelf sediments: Environment of deposition, alteration and hydrocarbon potential. International Journal of Coal Geology 72 (2), 89-123.

Dunkley Jones, T., Lunt, D. J., Schmidt, D. N., Ridgwell, A., Sluijs, A., Valdes, P. J., Maslin, M., 2013. Climate model and proxy data constraints on ocean warming across the Paleocene-Eocene Thermal Maximum. Earth Science Reviews 125, 123-145.
Dupuis, C., Aubry, M., Steurbaut, E., Berggren, W. A., Ouda, K., Magioncalda, R., Cramer, B. S., Kent, D. V., Speijer, R. P., Heilmann-Clausen, C., 2003. The Dababiya Quarry Section: Lithostratigraphy, clay mineralogy, geochemistry and paleontology. Micropaleontology 49 (1), 41-59.

Eldholm, O., Thomas, E., 1993. Environmental impact of volcanic margin formation. Earth and Planetary Science Letters 117 (3-4), 319-329.

Fabricius, K. E., Langdon, C., Humphrey, C., Noonan, S., Muehllehner, N., Fabricius, K. E., De'ath, G., Glas, M. S., Okazaki, R., Uthicke, S., Lough, J. M., 2011. Losers and winners in coral reefs acclimatized to elevated carbon dioxide concentrations. Nature Climate Change 1 (3), 165-169.

Faris, M., Abdelghany, O., Zahran, E., 2014. Upper Maastrichian to Lutetian nannofossil biostratigraphy, United Arab Emirates, west of the Northern Oman Mountains. Journal of African Earth Sciences 93, 42-56.

Frieling, J., Gebhardt, H., Huber, M., Adekeye, O.A., Akande, S. O., Reichart, G., Middelburg, J. J., Schouten, S., Sluijs, A., 2017. Extreme warmth and heat-stressed plankton in the tropics during the Paleocene-Eocene Thermal Maximum. Science Advances 3, 1-9.

Galeotti, S., Krishnan, S., Pagani, M., Lanci, L., Gaudio, A., Zachos, J.C., Monechi, S., Morelli, G., Lourens, L. J., 2010. Orbital chronology of Early Eocene hyperthermals from the Contessa Road section, central Italy. Earth and Planetary Science Letters 290, 192-200.

Giraldo-Gomez, V. M., Mutterlose, J., Podlaha, O. G., Speijer, R.P., Stassen, P., 2018. Benthic foraminifera and geochemistry across the Paleocene-Eocene Thermal Maximum interval in Jordan. Journal of Foraminiferal Research 48 (2), 100-120.

Giusberti, L., Rio, D., Agnini, C., Backman, J., Fornaciari, E., Tateo, F., Oddone, M., 2007. Mode and tempo of the Paleocene-Eocene thermal maximum in an expanded section from the Venetian pre-Alps. GSA Bulletin 119 (3-4), 391-412.

Gradstein, F. M., Ogg, J. G., Schmitz, M. D., Ogg, G. M., 2012. The Geologic Time Scale 2012, Elsevier.

Hallock, P., 1984. Distribution of selected species of living algal symbiont-bearing foraminifera on two Pacific coral reefs. The Journal of Foraminiferal Research 14 (4), 250-261.

Hallock, P., Glenn, E. C., 1986. Larger foraminifera: A tool for paleoenvironmental analysis of Cenozoic carbonate depositional facies. Palaios 1, 55-64.

Haq, B. U., Al-Qahtani, A. M., 2005. Phanerozoic cycles of sea-level change on the Arabian Platform. GeoArabia 10 (2), 127-160.

Haynes, J. R., 1965. Symbiosis, wall structure and habitat in foraminifera. Cushman Foundation, Foraminiferal Research Contribution 16, 40-43.

Hesselbo, S. P., 1996. Spectral gamma-ray logs in relation to clay mineralogy and sequence stratigraphy, Cenozoic of the Atlantic margin, offshore New Jersey. In: Mountain, G. S., Miller, K. G., Blum, P., Twitchell, D. (Eds.), Proceedings of the Ocean Drilling Program, Scientific 
Results 150, New Jersey continental slope and rise, 411-422.

Hikami, M., Ushie, H., Irie, T., Fujita, K., Kuroyanagi, A., Sakai, K., Nojiri, Y., Suzuki, A., Kawahata, H., 2011. Contrasting calcification responses to ocean acidification between two reef foraminifers harboring different algal symbionts. Geophysical Research Letters 38 (19), 1-5.

Hollis, C. J., Dickens, G. R., Field, B. D., Jones, C. M., Percy Strong, C., 2005. The Paleocene-Eocene transition at Mead Stream, New Zealand: A southern Pacific record of early Cenozoic global change. Palaeogeography, Palaeoclimatology, Palaeoecology 215, 313-343.

Hottinger, L., 1983. Processes determining the distribution of larger foraminifera in space and time. In: Meulenkamp, J. E. (Ed.), Reconstruction of Marine Paleoenvironments Vol. 30, Utrecht, 239-254.

Hottinger, L., 1998. Shallow benthic foraminifera at the Paleocene-Eocene boundary. Strata 9, 61-64.

Hottinger, L., 2009. The Paleocene and earliest Eocene foraminiferal Family Miscellaneidae: Neither nummulitids nor rotaliids. Notebooks on Geology 6, 1-41.

Hottinger, L., 2014. Paleogene larger Rotaliid Foraminifera from the western and central Neotethys, Springer, Switzerland, $195 \mathrm{p}$.

Keen, M. C., Racey, A., 1991. Lower Eocene ostracods from the Rusayl Shale Formation of Oman. Journal of Micropalaeontology 10 (2), 227-233.

Kennett, J. P., Stott, L. D., 1991. Abrupt deep-sea warming, paleoceanographic changes and benthic extinctions at the end of the Palaeocene. Nature 353, 225-228.

Khozyem, H., Adatte, T., Spangenberg, J.E., Keller, G., Tantawy, A. A., Ulianov, A., 2015. New geochemical constraints on the Paleocene-Eocene thermal maximum: Dababiya GSSP, Egypt. Palaeogeography, Palaeoclimatology, Palaeoecology 429, 117-135.

Knauth, L. P., Kennedy, M. J., 2009. The late Precambrian greening of the Earth. Nature Letters 460, 728-732.

Koch, P. L., Zachos, J. C., Gingerich, P. D., 1992. Correlation between isotope records in marine and continental reservoirs near the Paleocene/Eocene boundary. Nature 358, 319-322.

Komar, N., Zeebe, R. E., Dickens, G. R., 2013. Understanding long-term carbon cycle trends: The late Paleocene through the early Eocene. Paleoceanography 28, 650-662.

Kopp, R. E., Schumann, D., Raub, T. D., Powars, D. S., Godfrey, L. V., Swanson-Hysell, N. L., Maloof, A.C., Vali, H., 2009. An Appalachian Amazon? Magnetofossil evidence for the development of a tropical river-like system in the mid-Atlantic United States during the Paleocene-Eocene Thermal Maximum. Paleoceanography 24, 1-11.

Kotov, S., Pälike, H., 2018. QAnalyseries - a cross-platform time series tuning and analysis tool. American Geophysical Union, Fall Meeting, Washington D. C., USA.

Langer, M. R., 2008. Assessing the Contribution of Foraminiferan Protists to Global Ocean Carbonate Production. Journal of Eukaryotic Microbiology 55 (3), 163-169.
Lauretano, V., Hilgen, F. J., Zachos, J. C., Lourens, L. J., 2016. Astronomically tuned age model for the early Eocene carbon isotope events: A new high-resolution $\delta^{13} \mathrm{C}$ benthic record of ODP Site 1263 between 49 and $\sim 54$ Ma. Newsletters on Stratigraphy 49, 383-400.

Lauretano, V., Littler, K., Polling, M., Zachos, J. C., Lourens, L. J., 2015. Frequency, magnitude and character of hyperthermal events at the onset of the Early Eocene Climatic Optimum. Climate of the Past 11, 1313-1324.

Littler, K., Röhl, U., Westerhold, T., Zachos, J. C., 2014. A high-resolution benthic stable-isotope record for the South Atlantic: Implications for orbital-scale changes in late Paleocene-early Eocene climate and carbon cycling. Earth and Planetary Science Letters 401, 18-30.

Lourens, L. J., Sluijs, A., Kroon, D., Zachos, J. C., Thomas, E., Röhl, U., Bowles, J., Raffi, I., 2005. Astronomical pacing of late Palaeocene to early Eocene global warming events. Nature 435, 1083-1087.

Martini, E., 1971. Standard Tertiary and Quaternary calcareous nannoplankton zonation. In: Farinacci, A. (Ed.), Proceedings of the $2^{\text {nd }}$ International Conference on Planktonic Microfossils Roma, Rome, 739-785.

McInerney, F. A., Wing, S. L., 2011. The Paleocene-Eocene Thermal Maximum: A perturbation of carbon cycle, climate, and biosphere with implications for the future. Annual Review of Earth and Planetary Sciences 39, 489-516.

Miller, K. G., Janecek, T. R., Katz, M. E., Keil, D. J., 1987. Abyssal circulation and benthic foraminiferal changes near the Paleocene/Eocene boundary. Paleoceanography 2 (6), 741-761.

Monechi, S., Reale, V., Bernaola, G., Balestra, B., 2013. The Danian/Selandian boundary at Site 1262 (South Atlantic) and in the Tethyan Region: Biomagnetostratigraphy, evolutionary trends in fasciculiths and environmental effects of the Latest Danian Event. Marine Micropaleontology 98, 28-40.

Nolan, S. C., Skelton, P. W., Clissold, B. P., Smewing, J. D., 1990. Maastrichtian to Early Tertiary stratigraphy and palaeogeography of the Central and Northern Oman mountains. Geological Society, London, Special Publications 49, 495-519.

Orue-Etxebarria, X., Pujalte, V., Bernaola, G., Apellaniz, E., Baceta, J. I., Payros, A., Nuñez-Betelu, K., Serra-Kiel, J., Tosquella, J., 2001. Did the Late Paleocene thermal maximum affect the evolution of larger foraminifers? Evidence from calcareous plankton of the Campo Section (Pyrenees, Spain). Marine Micropaleontology 41, 45-71.

Paillard, D., Labeyrie, L., Yiou, P., 1996. Analyseries 1.0: a Macintosh software for the analysis of geophysical timeseries. Eos Transactions, AGU 77, 379 p.

Papazzoni, C.A., Pignatti, J., 2019. The Shallow Benthic Zones: SBZ or SB? $3^{\text {rd }}$ International Congress on Stratigraphy, STRATI 2019, Milan, Italy, 320 p.

Perch-Nielsen, K., 1985. Cenozoic calcareous nannofossils. In: Bolli, H. M., Saunders, J. B., Perch-Nielsen, K. (Eds.), Plankton Stratigraphy, Cambridge University Press, Cambridge, 427-554. 
Pignatti, J., Matteucci, R., Parlow, T., Fantozzi, P. L., 1998. Larger foraminiferal biostratigraphy of the Maastrichtian-Ypresian Wadi Mashib succession (South Hadramawt Arch, SE Yemen). Zeitschrift für Geologische Wissenschaften 26 (5-6), 609-635.

Prazeres, M., Uthicke, S., Pandolfi, J. M., 2015. Ocean acidification induces biochemical and morphological changes in the calcification process of large benthic foraminifera. Proceedings of the Royal Society B: Biological Sciences 282, 1-10.

Pujalte, V., Schmitz, B., Baceta, J. I., Orue-Etxebarria, X., Bernaola, G., Dinares-Turell, J., Payros, A., Apellaniz, E., Caballero, F., 2009. Correlation of the Thanetian-Ilerdian turnover of larger foraminifera and the Paleocene-Eocene thermal maximum: confirming evidence from the Campo area (Pyrenees, Spain). Geologica Acta 7 (1-2), 161-175.

Racey, A., 1995. Lithostratigraphy and larger foraminiferal (Nummulitid) biostratigraphy of the Tertiary of northern Oman. Micropaleontology 41, 1-123.

Razmjooei, M.J., Thibault, N., Kani, A., Ullmann, C. V., Jamali, A. M., 2020. Santonian-Maastrichtian carbon-isotope stratigraphy and calcareous nannofossil biostratigraphy of the Zagros Basin: Long-range correlation, similarities and differences of carbon-isotope trends at global scale. Global and Planetary Change 184 (103075), 1-14.

Renema, W., Bellwood, D. R., Braga, J. C., Bromfield, K., Hall, R., Johnson, K. G., Lunt, P., Meyer, C. P., McMonagle, L. B., Morley, R. J., O’Dea, A., Todd, J. A., Wesselingh, F. P., Wilson, M.E. J., Pandolfi, J. M., 2008. Hopping Hotspots: Global shifts in marine biodiversity. Science 321, 654-657.

Riechelmann, S., Mavromatis, V., Buhl, D., Dietzel, M., Hoffmann, R., Jöns, N., Kell-Duivestein, I., Immenhauser, A., 2018. Echinoid skeletal carbonate as archive of past seawater magnesium isotope signatures - Potential and limitations. Geochimica et Cosmochimica Acta 235, 333-359.

Röhl, U., Westerhold, T., Bralower, T. J., Zachos, J. C., 2007. On the duration of the Paleocene-Eocene thermal maximum (PETM). Geochemistry, Geophysics, Geosystems 8 (12), 1-13.

Scheibner, C., Speijer, R. P., 2008a. Decline of coral reefs during late Paleocene to early Eocene global warming. eEarth 3, 19-26.

Scheibner, C., Speijer, R. P., 2008b. Late Paleocene-early Eocene Tethyan carbonate platform evolution - A response to long- and short-term paleoclimatic change. Earth-Science Reviews 90 (3-4), 71-102.

Scheibner, C., Speijer, R.P., 2009. Recalibration of the Tethyan shallow-benthic zonation across the Paleocene-Eocene boundary: the Egyptian record. Geologica Acta 7 (1-2), 195-214.

Scheibner, C., Speijer, R. P., Marzouk, A. M., 2005. Turnover of larger foraminifera during the Paleocene-Eocene Thermal Maximum and paleoclimatic control on the evolution of platform ecosystems. Geology 33 (6), 493-496.

Schmidt, C., Kucera, M., Uthicke, S., 2014. Combined effects of warming and ocean acidification on coral reef Foraminifera Marginopora vertebralis and Heterostegina depressa. Coral Reefs 33, 805-818.

Schmitz, B., Pujalte, V., 2007. Abrupt increase in seasonal extreme precipitation at the Paleocene-Eocene boundary. Geology 35 (3), 215-218.

Schmitz, B., Speijer, R.P., Aubry, M.-P., 1996. Latest Paleocene benthic extinction event on the southern Tethyan shelf (Egypt): Foraminiferal stable isotopic $\left(\delta^{13} \mathrm{C}\right.$, $\left.\delta^{18} \mathrm{O}\right)$ records. Geology 24 (4), 347.

Schobben, M., Ullmann, C. V., Leda, L., Korn, D., Struck, U., Reimold, W. U., Ghaderi, A., Algeo, T. J., Korte, C., 2016. Discerning primary versus diagenetic signals in carbonate carbon and oxygen isotope records: An example from the Permian-Triassic boundary of Iran. Chemical Geology 422, 94-107.

Serra-Kiel, J., Gallardo-Garcia, A., Razin, P., Robinet, J., Roger, J., Grelaud, C., Leroy, S., Robin, C., 2016 b. Middle Eocene-Early Miocene larger foraminifera from Dhofar (Oman) and Socotra Island (Yemen). Arabian Journal of Geosciences 9 (5), 1-95.

Serra-Kiel, J., Hottinger, L., Caus, E., Drobne, K., Ferrandez, C., Jauhri, A. K., Less, G., Pavlovec, R., Pignatti, J., Samso, J. M., Schaub, H., Sirel, E., Strougo, A., Tambareau, Y., Tosquella, J., Zakrevskaya, E., 1998. Larger foraminiferal biostratigraphy of the Tethyan Paleocene and Eocene. Bulletin de la Societe Geologique de France 169 (2), 281-299.

Serra-Kiel, J., Vicedo, V., Razin, P., Grelaud, C., $2016 \mathrm{a}$. Selandian-Thanetian larger foraminifera from the lower Jafnayn Formation in the Sayq area (eastern Oman Mountains). Geologica Acta 14 (3), 315-333.

Shamrock, J. L., Watkins, D. K., 2012. Eocene calcareous nannofossil biostratigraphy and community structure from Exmouth Plateau, Eastern Indian Ocean (ODP Site 762). Stratigraphy 9 (1), 1-11.

Sharland, P. R., Archer, R., Casey, D. M., Davies, R. B., Hall, S. H., Heward, A., Horbury, A. D., Simmons, M. D., 2001. Chapter 4: Maximum Flooding Surfaces. In: Aplin, A., Archer, S., Bacon, M., Beck, I., Belopolsky, A., Biteau, J. J., Bjørlykke, K., Buck, S., Burley, S., Christie, M., Craig, J., Deming, D., Doré, A. G., Dromgoole, P. W., Flint, S. S., Geiger, S., Geluk, M., Goulty, N., Green, P. F., Harper, T., Henriquez, A., Hill, D., Japsen, P., Jolley, D. W., Kaldi, J., Larue, D., Lentini, M., Lovell, M., MacDonald, A., Mascle, A., Muggeridge, A., Nadeau, P., Prigmore, J., Ringrose, P., Schollnberger, W. E., Scotchman, I. C., Spitzer, R., Trudgill, B., Turner, J., Vejbæk, O., Whidden, K., Wood, R. (Eds.), Arabian Plate Sequence Stratigraphy. Gulf Petrolink, 127-301.

Shirayama, Y., Thornton, H., 2005. Effect of increased atmospheric $\mathrm{CO}_{2}$ on shallow water marine benthos. Journal of Geophysical Research C: Oceans 110 (9), 1-7.

Slotnick, B. S., Dickens, G. R., Nicolo, M. J., Hollis, C. J., Crampton, J.S., Zachos, J. C., Sluijs, A., 2012. Largeamplitude variations in carbon cycling and terrestrial weathering during the latest Paleocene and earliest Eocene: The record at Mead Stream, New Zealand. The Journal of Geology 120, 487-505. 
Sluijs, A., Brinkhuis, H., Schouten, S., Bohaty, S. M., John, C.M., Zachos, J. C., Reichart, G.-J., Sinninghe Damste, J. S., Crouch, E. M., Dickens, G. R., 2007. Environmental precursors to rapid light carbon injection at the Palaeocene/Eocene boundary. Nature Letters 450, 1218-1221.

Sluijs, A., Brinkhuis, H., Stickley, C. E., Warnaar, J., Williams, G. L., Fuller, M., 2003. Dinoflagellate cysts from the Eocene-Oligocene transition in the Southern Ocean: Results from ODP Leg 189. In: Exon, N. F., Kennett, J. P., Malone, M. J. (Eds.), Proceedings of the Ocean Drilling Program, Scientific Results Vol. 189.

Sluijs, A., Dickens, G. R., 2012. Assessing offsets between the $\delta^{13} \mathrm{C}$ of sedimentary components and the global exogenic carbon pool across early Paleogene carbon cycle perturbations. Global Biogeochemical Cycles 26, 1-14.

Sluijs, A., Schouten, S., Donders, T. H., Schoon, P. L., Röhl, U., Reichart, G.-J., Sangiorgi, F., Kim, J.-H., Sinninghe Damsté, J. S., Brinkhuis, H., 2009. Warm and wet conditions in the Arctic region during Eocene Thermal Maximum 2. Nature Geoscience 2, 777-780.

Sluijs, A., Schouten, S., Pagani, M., Woltering, M., Brinkhuis, H., Sinninghe Damsté, J. S., Dickens, G. R., Huber, M., Reichart, G., Stein, R., Matthiessen, J., Lourens, L. J., Pedentchouk, N., Backman, J., Moran, K., 2006. Subtropical Arctic Ocean temperatures during the Palaeocene/Eocene thermal maximum. Nature 441, 610-613.

Sluijs, A., Van Roij, L., Harrington, G. J., Schouten, S., Sessa, J. A., Levay, L. J., Reichart, G. J., Slomp, C. P., 2014. Warming, euxinia and sea level rise during the Paleocene-Eocene thermal maximum on the gulf coastal plain: Implications for ocean oxygenation and nutrient cycling. Climate of the Past 10 (4), 1421-1439.

Speijer, R. P., Scheibner, C., Stassen, P., Morsi, A. M. M., 2012. Response of marine ecosystems to deep-time global warming: A synthesis of biotic patterns across the Paleocene-Eocene thermal maximum (PETM). Austrian Journal of Earth Sciences 105 (1), 6-16.

Speijer, R. P., Schmitz, B., 2000. A synthesis of biotic and stratigraphic data from the Middle East on late Paleocene global change. GFF 122 (1), 152-153.

Speijer, R. P., Wagner, T., 2002. Sea-level changes and black shales associated with the late Paleocene thermal maximum: Organic-geochemical and micropaleontologic evidence from the southern Tethyan margin (Egypt-Israel). Geological Society of America Special Paper 356, 533-549.

Spötl, C., Vennemann, T. W., 2003. Continuous flow isotope ratio mass spectrometric analysis of carbonate minerals. Rapid Communications in Mass Spectrometry 17, 1004-1006.

Stap, L., Lourens, L. J., van Dijk, A., Schouten, S., Thomas, E., 2010. Coherent pattern and timing of the carbon isotope excursion and warming during Eocene Thermal Maximum 2 as recorded in planktic and benthic foraminifera. Geochemistry, Geophysics, Geosystems 11, 1-10.

Stap, L., Sluijs, A., Thomas, E., Lourens, L. J., 2009. Patterns and magnitude of deep sea carbonate dissolution during Eocene Thermal Maximum 2 and H2, Walvis Ridge, southeastern Atlantic Ocean. Paleoceanography 24, 1-13.

Thomas, E., 1989. Development of Cenozoic deep-sea benthic foraminiferal faunas in Antarctic waters. Geological Society Special Publication 47, 283-296.

Thomas, E., 1998. Biogeography of the late Paleocene benthic foraminiferal extinction. In: Aubry, M. P., Lucas, S., Berggren, W. A. (Eds.), Late Paleocene-Early Eocene Climatic and Biotic Events in the Marine and Terrestrial Records, Columbia University Press, New York, 214-243.

Thomas, E., 2007. Cenozoic mass extinctions in the deep sea: What perturbs the largest habitat on Earth? The Geological Society of America Special Paper 424, 1-23.

Thomas, E., Boscolo-Galazzo, F., Balestra, B., Monechi, S., Donner, B., Röhl, U., 2018. Early Eocene Thermal Maximum 3: Biotic response at Walvis Ridge (SE Atlantic Ocean). Paleoceanography and Paleoclimatology 33, $1-22$.

Thomas, E., Shackleton, N. J., 1996. The Paleocene-Eocene benthic foraminiferal extinction and stable isotope anomalies. In: Knox, R. W. O., Corfield, R. M., Dunay, R. E. (Eds.), Correlation of the Early Paleogene in Northwest Europe. Geological Society Special Publication 101, 401-441.

Thomas, E., Zachos, J. C., Bralower, T. J., 2000. Deep-sea environments on a warm earth: latest Paleocene-early Eocene. In: Huber, B. T., MacLeod, K. G., Wing, S. L. (Eds.), Warm Climates in Earth History, Cambridge University Press, Cambridge, UK, 132-160.

Tomas, S., Frijia, G., Bomelburg, E., Zamagni, J., Perrin, C., Mutti, M., 2016. Evidence for seagrass meadows and their response to paleoenvironmental changes in the early Eocene (Jafnayn Formation, Wadi Bani Khalid, N Oman). Sedimentary Geology 341, 189-202.

Townsend, C. R., Scarsbrook, M. R., Doledec, S., 1997. The intermediate disturbance hypothesis, refugia, and biodiversity in streams. Limnology and Oceanography 42 (5), 938-949.

Tucker, M.E., Wright, V.P., 1990. Carbonate Sedimentology. Blackwell Science Publications, 482 p.

Ullmann, C. V., Gale, A. S., Huggett, J., Wray, D., Frei, R., Korte, C., Broom-Fendley, S., Littler, K., Hesselbo, S. P., 2018. The geochemistry of modern calcareous barnacle shells and applications for palaeoenvironmental studies. Geochimica et Cosmochimica Acta 243, 149-168.

Ullmann, C. V., Korte, C., 2015. Diagenetic alteration in low-Mg calcite from macrofossils: a review. Geological Quaterly 59 (1), 3-20.

Uthicke, S., Momigliano, P., Fabricius, K. E., 2013. High risk of extinction of benthic foraminifera in this century due to ocean acidification. Scientific Reports 3, 1-5.

Varol, O., 1989. Paleocene calcareous nannofossil biostratigraphy. In: Crux, J. A., Heck, S. E. (Eds.), Nannofossils and their applications. Ellis Horwood Limited, 267-310. 
Vogel, N., Uthicke, S., 2012. Calcification and photobiology in symbiont-bearing benthic foraminifera and responses to a high $\mathrm{CO}_{2}$ environment. Journal of Experimental Marine Biology and Ecology 424-425, 15-24.

Westerhold, T., Röhl, U., Donner, B., McCarren, H. K., Zachos, J. C., 2011. A complete high-resolution Paleocene benthic stable isotope record for the central Pacific (ODP Site 1209). Paleoceanography 26 (2), 1-13.

Westerhold, T., Röhl, U., Donner, B., Zachos, J. C., 2018. Global extent of early Eocene hyperthermal events: A new Pacific benthic foraminiferal isotope record from Shatsky Rise (ODP Site 1209). Paleoceanography and Paleoclimatology 33, 626-642.

Westerhold, T., Röhl, U., Frederichs, T., Agnini, C., Raffi, I., Zachos, J.C., Wilkens, R. H., 2017. Astronomical calibration of the Ypresian timescale: Implications for seafloor spreading rates and the chaotic behavior of the solar system? Climate of the Past 13, 1129-1152.

Westerhold, T., Röhl, U., Raffi, I., Fornaciari, E., Monechi, S., Reale, V., Bowles, J., Evans, H. F., 2008. Astronomical calibration of the Paleocene time. Palaeogeography, Palaeoclimatology, Palaeoecology 257, 377-403.

Williams, G. L., Fensome, R. A., MacRae, R. A., 2017. The Lentin and Williams Index of Fossil Dinoflagellates, 2017 Edition. American Association of Stratigraphic Palynologists Foundation, AASP Contributions Series Number 48, 1-1097.

Winguth, A. M. E., Thomas, E., Winguth, C., 2012. Global decline in ocean ventilation, oxygenation, and productivity during the Paleocene-Eocene Thermal Maximum: Implications for the benthic extinction. Geology 40 (3), 263-266.

Young, J. R., Bown, P. R., Lees, J. A., 2019. Nannotax3. International Nannoplankton Association, Accessed: $<$ http://www.mikrotax.org/Nannotax3, >.

Zachos, J. C., Dickens, G. R., Zeebe, R. E., 2008. An early Cenozoic perspective on greenhouse warming and carbon-cycle dynamics. Nature 451, 279-283.

Zachos, J. C., Mccarren, H., Murphy, B., Röhl, U., Westerhold, T., 2010. Tempo and scale of late Paleocene and early Eocene carbon isotope cycles: Implications for the origin of hyperthermals. Earth and Planetary Science Letters 299, 242-249.

Zachos, J. C., Pagani, M., Sloan, L., Thomas, E., Billups, K., 2001. Trends, rhythms, and aberrations in global climate $65 \mathrm{Ma}$ to present. Science 292, 686-693.

Zachos, J. C., Röhl, U., Schellenberg, S. A., Sluijs, A., Hodell, D. A., Kelly, D.C., Thomas, E., Nicolo, M., Raffi, I., Lourens, L.J., McCarren, H., Kroon, D., 2005. Rapid acidification of the ocean during the Paleocene-Eocene Thermal Maximum. Science 308, 1611-1615.

Zachos, J. C., Schouten, S., Bohaty, S., Quattlebaum, T., Sluijs, A., Brinkhuis, H., Gibbs, S. J., Bralower, T. J.,
2006. Extreme warming of mid-latitude coastal ocean during the Paleocene-Eocene Thermal Maximum: Inferences from $\mathrm{TEX}_{86}$ and isotope data. Geology 34 (9), 737-740.

Zachos, J.C., Wara, M. W., Bohaty, S., Delaney, M.L., Petrizzo, M. R., Brill, A., Bralower, T. J., Premoli-Silva, I., 2003. A transient rise in tropical sea surface temperature during the Paleocene-Eocene Thermal Maximum. Science 302, 1551-1554.

Zamagni, J., Mutti, M., Košir, A., 2008. Evolution of shallow benthic communities during the Late Paleocene-earliest Eocene transition in the Northern Tethys (SW Slovenia). Facies 54 (1), 25-43.

Zamagni, J., Mutti, M., Kosir, A., 2012. The evolution of mid Paleocene-early Eocene coral communities: How to survive during rapid global warming. Palaeogeography, Palaeoclimatology, Palaeoecology 317-318, 48-65.

Zeebe, R. E., Dickens, G. R., Ridgwell, A., Sluijs, A., Thomas, E., 2014. Onset of carbon isotope excursion at the Paleocene-Eocene thermal maximum took millennia, not 13 years. Proceedings of the National Academy of Sciences 111 (12), 1062-1063.

Zeebe, R. E., Lourens, L. J., 2019. Solar system chaos and the Paleocene-Eocene boundary age constrained by geology and astronomy. Science 365 (6456), 926-929.

Zeebe, R. E., Ridgwell, A., Zachos, J. C., 2016. Anthropogenic carbon release rate unprecedented during the past 66 million years. Nature Geoscience 9 (4), 325-329.

Zhang, Q., Wendler, I., Xu, X., Willems, H., Ding, L., 2017. Structure and magnitude of the carbon isotope excursion during the Paleocene-Eocene thermal maximum. Gondwana Research 46, 114-123.

Zhang, Q., Willems, H., Ding, L., 2013. Evolution of the Paleocene-Early Eocene larger benthic foraminifera in the Tethyan Himalaya of Tibet, China. International Journal of Earth Sciences (Geologische Rundschau) 102, 1427-1445.

Zhang, Q., Willems, H., Ding, L., Xu, X., 2018. Response of larger benthic foraminifera to the Paleocene-Eocene thermal maximum and the position of the Paleocene/ Eocene boundary in the Tethyan shallow benthic zones: Evidence from south Tibet. The Geological Society of America Bulletin 131 (1-2), 84-98.

Ziegler, M. A., 2001. Late Permian to Holocene paleofacies evolution of the Arabian Plate and its hydrocarbon occurrences. GeoArabia 6 (3), 445-504.

Manuscript received: September 26, 2019

Revisions required: March 25, 2020

Revised version received: May 26, 2020

Manuscript accepted: May 27, 2020 


\section{The pdf version of this paper includes an electronic supplement}

Please save the electronic supplement contained in this pdf-file by clicking the blue frame above. After saving rename the file extension to .zip (for security reasons Adobe does not allow to embed .exe, .zip, .rar etc. files).

\section{Table of contents - Electronic Supplementary Material (ESM)}

Table S1. 2 standard deviation repeatability for standards Carrara Marble (CAR) and Namibia Carbonatite (NCA) used in stable isotope analyses.

Table S2. Suite of analysed elements using ICP-OES, wavelengths ( $\mathrm{nm}$ ) and 6sd baseline variability in $\mathrm{ng} / \mathrm{g}$ and converted to equivalent molar ratios ( $\mathrm{mmol} / \mathrm{mol}$ ) given a nominal Ca concentration of $25 \mu \mathrm{g} / \mathrm{g}$ in analysed solution.

Table S3. Detailed counts of the palynomorph assemblages from Core A. The dominant component of all three samples analysed was amorphous organic matter (AOM), likely of a marine origin.

Figure S1. Images of the three facies types. Facies type 1: Marl with few or no bioclasts. Facies type 2: LBF-rich bioclastic wackestone/packstone. Facies type 3: Bioclastic grainstone with LBF, gastropods, bivalves, solitary corals.

Figure S2. Left hand side shows reflected light vs. cathodoluminescence images of Lockhartia sp. (taken from sample at $0.2 \mathrm{~m}$ ) showing little luminescence within LBF or surrounding sediment. Right hand side shows $\delta^{13} \mathrm{C}$ vs. $\delta^{18} \mathrm{O}$ cross-plot of pre-CIE values (below $\sim 70 \mathrm{~m}$ ), which shows a low $\mathrm{R}^{2}$ value thus suggesting meteoric diagenesis has not affected the bulk isotopic values in a systematic manner. Error bars are 2sd of the standard CAR (Table S1).

Figure S3. Core A sedimentation rates in red circles calculated by tying the Core A stratigraphy to that from orbitally tuned deep sea ODP Site 1262 (Fig. 7). The high-resolution sedimentation rates of South Atlantic ODP Site 1262 (Barnet et al. 2019) are shown with a blue line. Site 1262 data shows an increase into the early Eocene, after the decline at the PETM. This trend is also observed in the Core A record.

Figure S4. Alternative Core A and ODP Site 1262 correlations constructed in QAnalyseries (Paillard et al. 1996, Kotov and Pälike 2018). Black circles and solid/dashed black lines indicate sedimentation rates, grey boxes indicate core gaps, and vertical black arrows show tie points used to create the alternative age models. Facies types are shown at the top of the figure: ps = packstone; ws = wackestone; gs = grainstone. Explanations about these alternative age models and the Figure 7 age model are provided below in the Supplementary Information. 